GA-A16062

UC-77

\title{
REQUIREMENTS FOR THE GCFR PLENUM STREAMING EXPERIMENT
}

\author{
by \\ R. G. PERKINS, C. A. ROUSE, and C. J. HAMILTON
}

Prepared under

Contract DE-AT03-76SF71023

for the San Francisco Operations Office

of the Department of Energy

DATE PUBLISHED: SEPTEMBER 1980 


\section{DISCLAIMER}

This report was prepared as an account of work sponsored by an agency of the United States Government. Neither the United States Government nor any agency Thereof, nor any of their employees, makes any warranty, express or implied, or assumes any legal liability or responsibility for the accuracy, completeness, or usefulness of any information, apparatus, product, or process disclosed, or represents that its use would not infringe privately owned rights. Reference herein to any specific commercial product, process, or service by trade name, trademark, manufacturer, or otherwise does not necessarily constitute or imply its endorsement, recommendation, or favoring by the United States Government or any agency thereof. The views and opinions of authors expressed herein do not necessarily state or reflect those of the United States Government or any agency thereof. 


\section{DISCLAIMER}

Portions of this document may be illegible in electronic image products. Images are produced from the best available original document. 
This report was prepared as an account of work sponsored by an agency of the United States Government. Neither the United States Government nor any agency thereof, nor any of their employees, makes any warranty, express or implied, or assumes any legal liability or responsibility for the accuracy, completeness, or usefulness of any information, apparatus, product, or process disclosed, or represents that its use would not infringe privately owned rights. Reference herein to any specific commercial product, process, or service by trade name, trademark, manufacturer, or otherwise, does not necessarily constitute or imply its endorsement, recommendation, or favoring by the United States Government or any agency thereof. The views and opinions of authors expressed herein do not necessarily state or reflect those of the United States Government or any agency thereof.

\author{
Printed in the United States of America \\ Available from \\ Department of Energy Technical Information Center \\ P.0. Box 62 \\ Oak Ridge, Tennessee 37830 \\ NTIS price codes \\ Printed copy: A08 \\ Microfiche copy: $\mathrm{A} 01$
}




\title{
GA-A16062
}

UC-77

\section{REQUIREMENTS FOR THE GCFR PLENUM STREAMING EXPERIMENT}

\author{
by \\ R. G. PERKINS, C. A. ROUSE, and C. J. HAMILTON
}

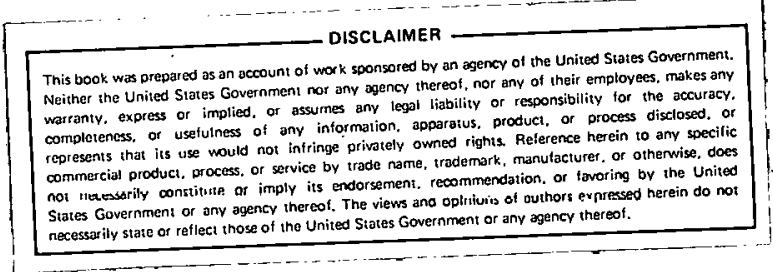

Prepared under

Contract DE-AT03-76SF71023

for the San Francisco Operations Office

of the Department of Energy

\section{GENERAL ATOMIC PROJECT 6113 DATE PUBLISHED: SEPTEMBER 1980}


THIS PAGE

\section{WAS INTENTIONALLY \\ LEFT BLANK}




\begin{abstract}
This report gives the experiment objectives and generic descriptions of experimental configurations for the gas-cooled fast breeder reactor (GCFR) plenum shield experiment. Oak Ridge National Laboratory will provide detailed specifications of configuration geometry and measurement sequences.

This report defines four experiment phases. Each phase represents a distinct area of uncertainty in computing radiation transport from the GCFR core to the plenums, through the upper and lower plenum shields, and ultimately to the prestressed concrete reactor vessel (PCRV) liner:
\end{abstract}

1. The shield heterogeneity phase will measure neutron streaming in narrow passages between large bodies of graphite and steel representing heterogeneities in GCFR laminated shields.

2. The exit shield simulation phase will quantify uncertainties in computing transport out of the core through prototypical mockups of fuel assembly exit shields.

3. The plenum streaming phase will quantify uncertainties in computing transport and scattering in the large low-density plenums.

4. The plenum shield simulation phase will quantify uncertainties in computing deep penetration through prototypical mockups of shield modules contained in the upper and lower reactor plenums. 
THIS PAGE

\section{WAS INTENTIONALLY LEFT BLANK}


CONTENTS

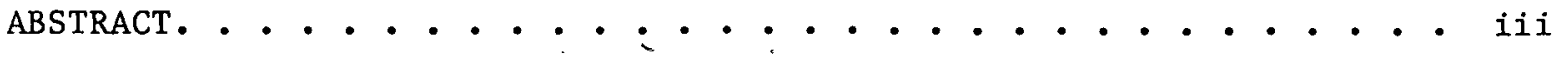

1. TNTRODUCTION. . . . . . . . . . . . . . . . . . 1-1

2. CONCEPTUAL SHIELD DESIGN FOR.UPFLOW GCFR. . . . . . . . . 2-1

3. EXPERIMENT OBJECTIVES .................. . . . . . . .

4. TEST REQUIREMENTS ... . . . . . . . . . . . . . 4-1

4.1. Technical Products . . . ........... . 4-1

4.2. Experiment Phases. . . . . . . . . . . 4-1

4.2.1. Shield Heterogeneity Phase... . . . . . 4-2

4.2.2. Exit Shield Simulation Phase... . . . . . 4-8

4.2.3. Plenum Streaming Phase... . . . . . . 4-20

4.2.4. Plenum Shield Simulation Phase......... 4-30

5. QuAltTY ASSURANCE . . . . . . . . . . . . . . . 5-1

6. REFERENCES. . . . . . . . . . . . . . . . . 6-1

\section{FIGURES}

2-1. 300-MW(e) GCFR NSSS. . . . . . . . . . . . . 2-2

2-2. Cross section of GCFR demonstration plant reactor cavity . . 2-3

2-3. Lifetime radiation exposure criteria for permanent GCFR structural steel components. . . . . . . . . . . . 2-5

2-4. GCFR shielding system components . . . . . . . . . . . 2-7

2-5. GCFR radial reflector shield assembly. . . . . . . . . . 2-9

2-6. GCFR upflow fuel assembly. . . . . . . ..... 2-10

2-7. GCFR grid plate shielding. . . . . . . . . . . . . 2-12

2-8. Fuel assembly exit shields. . . . . . . . . . . 2-13.

2-9. Control assembly general arrangement . . . . . . . . . 2-15

2-10. Horizontal cut through reactor plenum showing flow-through plenum shield concepts . . . . . . . . . . . . 2-17 


\section{FIGURES (Continued)}

4-1. Configuration I: all graphite . . . . . . . . . . . 4-4

4-2. Configuration II: carbon steel and graphite, single gap . . 4-5

4-3. Configuration III: carbon steel and graphite, three gaps. . 4-6

4-4. Configuration IV: graphite offset gap . . . . . . . . . . . 4-7

4-5. DOT IV $R-Z$ model of seven assembly cell with central control

rod fully inserted ... . . . . . . . . . . . 4-9

4-6. DOT IV $R-Z$ model of seven assembly cell with central control.

rod fully withdrawn. . . . . . . . . . . . . . 4-10

4-7. Total 30-EPY fluence with control rod inserted ...... . 4-11

4-8. Total 30-EPY fluence with control rod withdrawn. . . . . . 4-12

4-9. Configuration I: seven fuel assemblies. . . . . . . . . 4-13

4-10. Configuration II: seven fuel assemblies [nine rods per assembly, 0.635 ( $1 / 4-$ in.) duct gap] with exit shields and no control rod................. 4-19

4-11. Configuration III: 60-cm (23.6-in.) control rod in core (fully inserted) . . ................ . . 4-21

4-12. Configuration IV: 120-cm (47.24-in.) control rod in core and blankets (fully inserted). . . . . . . . . . . . . 4-22

4-13. Configuration V: 120-cm (47.24-in.) control rod in blanket and exit shield (fully withdrawn). . . . . . . . . . 4-23

4-14. Configuration VI: control assembly with peripheral shield only, no control rod . . . . . . . . . . . . . 4-24

4-15. Configuration VII: 60-cm (23.6-in.) control rod in core with peripheral shield. . . . . . . . . . . . . . 4-25

4-16. Configuration VIII: 120-cm (47.24-in.) control rod in core and blankets (fully inserted) with peripheral shield . . . . 4-26

4-17. Configuration IX: 120-cm (47.24-in.) control rod in blanket and exit shield (fully withdrawn) with peripheral shield . . . 4-27

4-18. Plenum streaming phase mockup. . . . . . . . . . . . 4-29

4-19. Plenum shield phase mockup.............. . . 4-31 


\section{TABLES}

1-1. Experimental program . . . . . . . . . . . . . 1-3

4-1. Measurement configuration matrix for the shield heterogeneity phase. . . . . . . . . . . . . . . . . . 4-3

4-2. Total 30-EPY fluence at important locations. . . . . . . 4-14

4-3. Total fission source for several experimental configurations - 4-16

4-4. Comparison of control rod mockup with $\mathrm{B}_{4} \mathrm{C}$ and graphite . . 4 4-17

4-5. Measurement configuration matrix for the exit shield phase . 4-18 


\section{INTRODUCTION AND BACKGROUND}

The purpose of the gas-cooled fast breeder reactor (GCFR) shielding physics experimental program (Ref. 1) is to simulate and verify shielding problems and solutions unique to the GCFR. It will validate GCFR calculational methods and models for neutronic configurations (dimensions and materials). This incremental program has attempted to use calculated methods and data validated in other reactor programs [primarily the liquid metal fast breeder reactor (LMFBR)] program. The following areas are unique to GCFR shielding:

1. Neutron streaming between fuel rods and assembly ducts.

2. Neutron streaming in large control channels.

3. Neutron streaming and scattering in large plenum (void) regions.

4. Deep penetration with significant heterogeneities.

5. Specific shield configurations with complex geomctries, heterogeneities, and material arrangements.

When the shielding experimental program is completed, sufficient data and confidence will exist to establish the shield geometric envelope. The shielding experimental program must be completed early in the GCFR program, since several long-lead-time items [prestressed concrete reactor vessel (PCRV) design, liner procurement, and fabrication] depend on the derived information. If the program is completed in time, retrofitting will not be needed, and potential schedule bottlenecks, such as occurred in the Fast Test Reactor and Clinch River Breeder Reactor Programs, will be averted. 
Table 1-1 outlines the GCFR experimental program, which consists of three major experiments:

1. Grid plate shield experiment (1978).

2. Radial shield experiment (1979).

3. Plenum streaming experiment (1980-81).

The grid plate shield experiment (Refs. 2,3), conducted in 1978, demonstrated the adequacy of the grid plate shield configuration. It validated the two-dimensional transport analytical techniques used for this shield design. It also characterized the sensitivity of grid plate dose to fuel volume fraction and gaps between elements. It measured local fluxes using $0.635-\mathrm{cm}(1 / 4-\mathrm{in}$.) Hornyak buttons developed specifically for this application. Oak Ridge National Laboratory (ORNL) completed analysis of the experimental results in 1979 with unusually good agreement between experiment and calculation. The experiment mitigated concerns about local flux peaking in the grid plate.

The radial shield experiment (Ref. 4), completed in October 1979, measured neutron production and penetration through both thorium and uranium blankets. It measured flux levels through stainless steel, graphite, and $\mathrm{B}_{4} \mathrm{C}$ structures, representing the reflector/shield assemblies and the outer radial shields, in approximately prototypical slab configurations. Preliminary analysis of the experimental results appears consistent with the good agreement observed in prior experiments. Analysis of the results will be completed in 1980 .

The plenum streaming experiment has four distinct phases:

1. Shield heterogeneity.

2. Exit shield simulation.

3. Plenum streaming.

4. Plenum shield simulation. 
TABLE $1-1$

EXPERIMENTAL PROGRAM

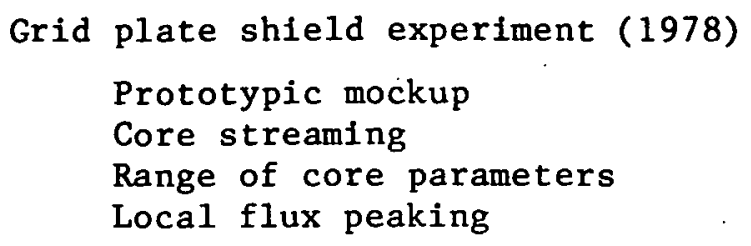

Grid plate shield experiment (1978)

Prototypic mockup

Core streaming

Range of core parameters

Local flux peaking

Radial shield experiment (1979)

Slap deep penetration mockup

Thorium and uranium blankets

Laminated shields

Alternate material arrangements

Plenum streaming experiment (1980)

Phase 1. Shield heterogeneity

Phase 2. Exit shield simulation

Phase 3. Plenum streaming

Phase 4. Plenum shield simulation 
The overall objective of the plenum streaming experiment is to quantify uncertainties in computing radiation transport from the GCFR core to the plenums, through the upper and lower plenum shields, and ultimately to the PCRV liner. The four phases address four different types of uncertainties: (1) shield heterogeneities, (2) exit shield streaming, (3) plenum streaming and scattering, and (4) deep penetration.

The shield heterogeneity phase, now under way, will measure neutron streaming in narrow passages between large bodies of graphite and steel; it will measure both straight and angled configurations. Such heterogeneities, associated with gaps between shields and materials, result from manufacturing and construction tolerances, thermal expansion, and steel encasement of graphite bricks in the laminated shields. Hornyak button detectors will especially measure local flux peaking for a range of expected gap sizes.

The exit shield simulation phase, to be completed at the end of September 1980, will quantify uncertainties in computing the combined effects of streaming in the core, blankets, control rod channels, and prototypical fuel assembly exit shields. The basic experimental configuration is identical to that of the grid plate shield experiment, except that exit shields replace grid plate shield test modules. Measurements will be made with the control rod at different positions, where the central assembly is a control assembly mockup.

The plenum streaming phase, scheduled for October 1980, will quantify uncertainties in computing radiation transport in the large upper and lower plenums. Calculational uncertainties are associated with long mean free paths and scattering off plenum shield surfaces. The experiment will consist of a large cavity mockup. The configuration used in the exit shield phase, with seven fuel assemblies and their exit shields, will provide the cavity source. 
The plenum shield simulation phase will quantify uncertainties in computing deep penetration through prototypical upper and lower plenum (flow-through) shield modules. The experiment is in slab geometry, where prototypical mockups are placed behind an appropriate spectrum modifier. 


\section{CONCEPTUAL SHIELD DESIGN FOR UPFLOW GCFR}

Figure 2-1 shows a cutaway of the 300-MW(e) GCFR demonstration plant nuclear steam supply system (NSSS). The entire primary system is contained within the PCRV. The PCRV is reinforced with rebar and is prestressed after the concrete construction by longitudinal tendons and circumferential wire wrappings. Separate cavities house the reactor core and the components of three independent main coolant loops and three independent auxiliary coolant loops. Core cooling is provided by helium at about $10 \mathrm{MPa}$ (100 atm).

Figure 2-2 shows a cross section of the reactor cavity and identifies the primary system reactor internal components. The reactor shielding system primarily protects the reactor primary system components from detrimental irradiation-induced material damage and heating. Because of large PCRV attenuation, biological or plant shielding concerns are limited to leakage from PCRV cavity closure plugs and penetrations and activation of certain components (e.g., helium circulators and s'steam generators).

The shielding protects two groups of primary system components: (1) primary coolant system boundary (PCSB) components and (2) reactor internal components. The PCSB comprises the PCRV, including its rebar and prestressing tendons and the PCRV therwal barrier, liner, and cooling system. All interior cavity surfaces have a ferritic steel liner, making the PCRV leak tight. The inner surface of the steel liner is insulated by a thermal barrier, consisting of a stepl plate and insulation. Cooling tubes, located on the concrete side of the liner, carry water to keep the liner and concrete near a minimum of about $100^{\circ} \mathrm{C}$.

The reactor internal components comprise all components in the spatial envelope inside the PCSB and outside the core. Helium coolant at about $300^{\circ} \mathrm{C}$ from the circulators enters a lower plenum containing laminated shielding. It then flows to the core through the reactor grid plate, which 


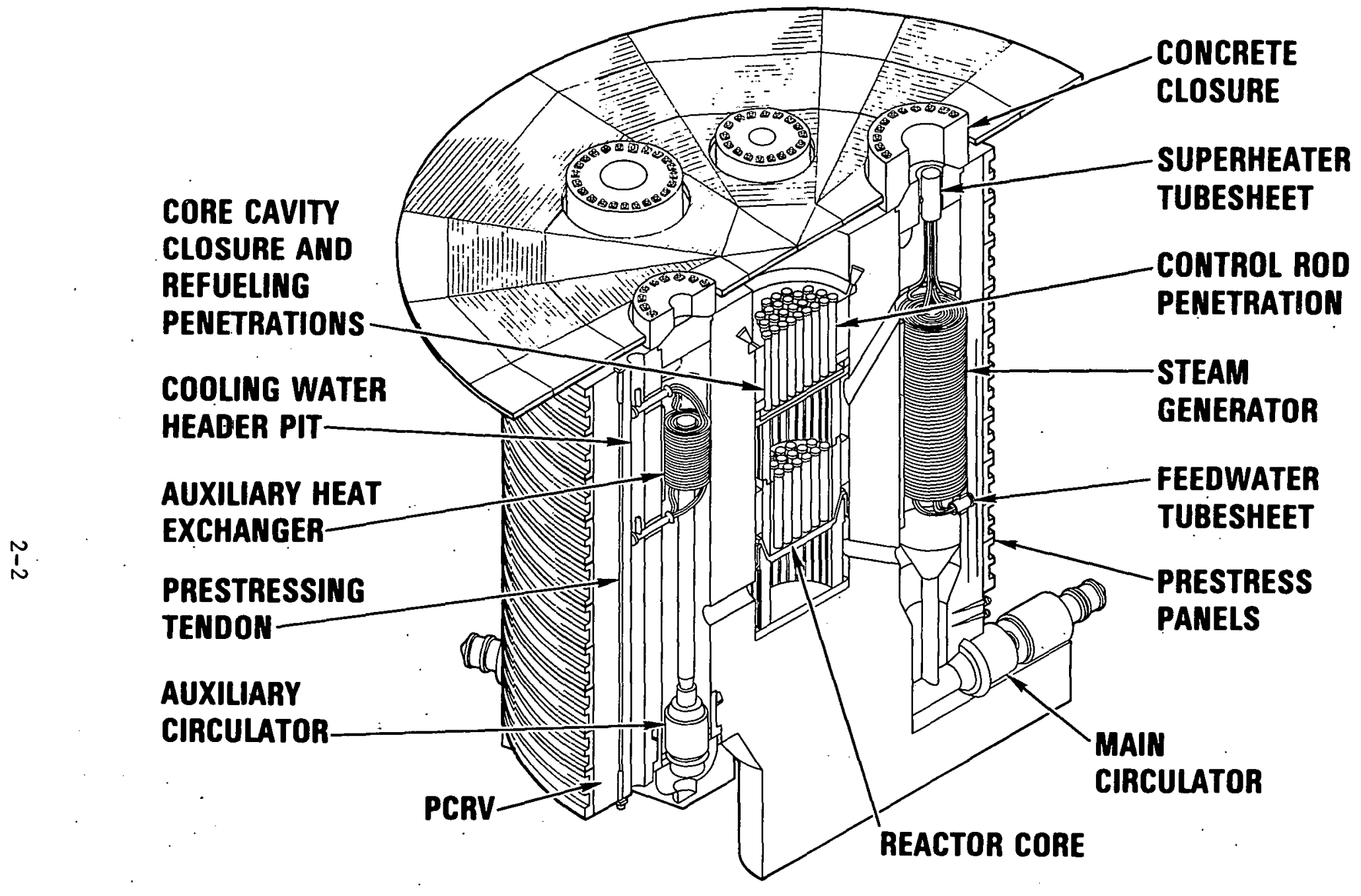

Fig. 2-1. 300-MW(e) GCFR NSSS 


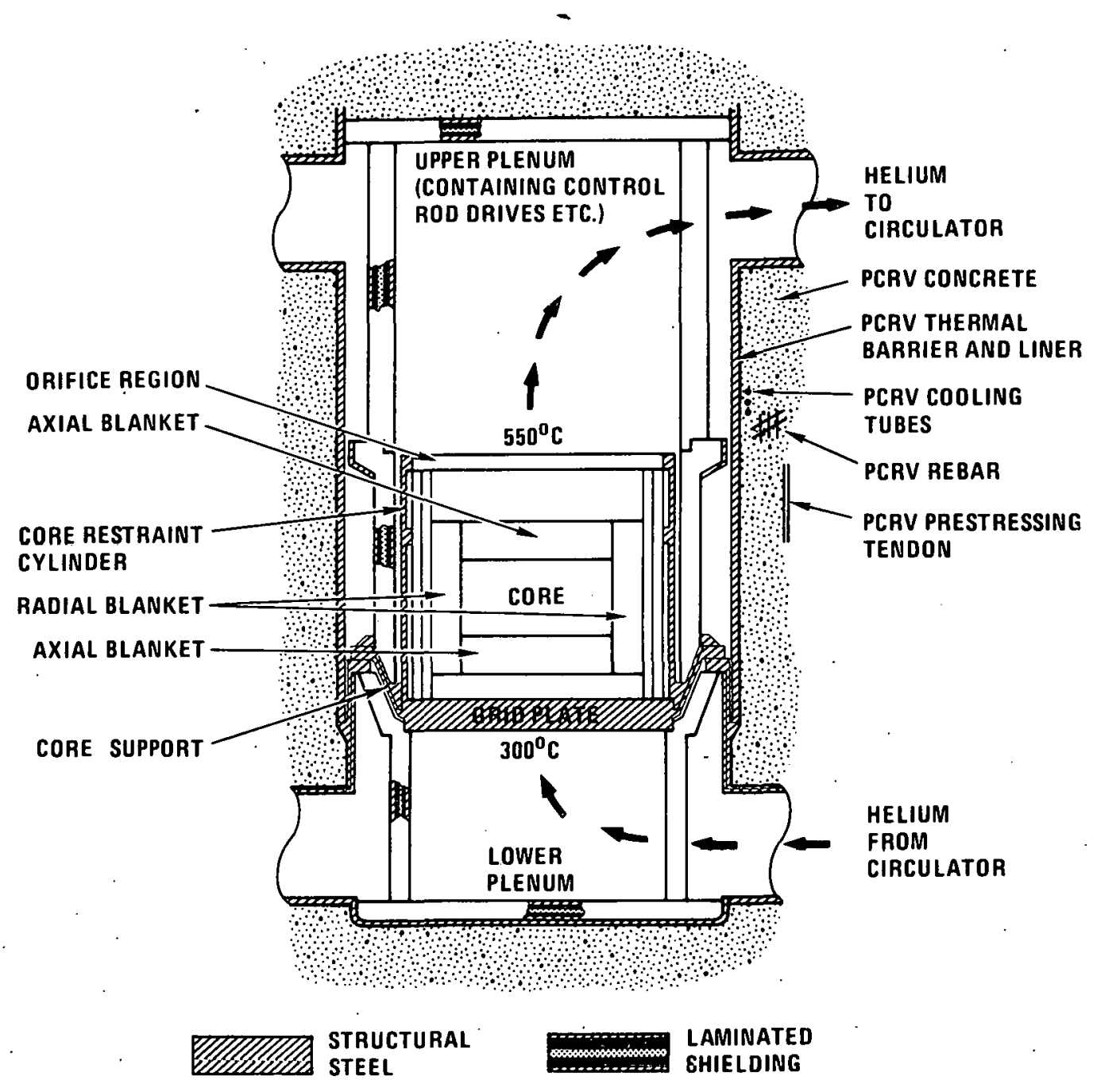

Fig. 2-2. Cross section of GCFR demonstration plant reactor cavity 
consists of a solid stainless steel plate, about $0.6 \mathrm{~m}$ ( $2 \mathrm{ft}$ ) thick, with closely spaced holes to accommodate the lower circulator section (nozzle) of the hexagonal core assemblies. A core support structure transmits the core load to the PCRV liner, and a core restraint cylinder limits core lateral movement. The grid plate, core support, and restraint structures are all cooled with the $300^{\circ} \mathrm{C}$ inlet helium.

The reactor core is surrounded by an axial blanket and three rows of radial blanket assemblies. The helium exits the core at about $550^{\circ} \mathrm{C}$ into the large upper plenum, which contains control rod drives, instrumentation, and more laminated shielding. It then enters the return ducts to the steam generator.

Setting material irradiation exposure limits for fast breeder reactors is difficult without an adequate irradiation effects data base. Applicable American Society of Mechanical Engineers (ASME) codes give meager guidance on how to incorporate irradiation effects into structural design criteria (Refs. 5 through 7). As a consequence scarce data, the selected criteria and their associated exposure limits are highly conservative.

Figure 2-3 lists the lifetime radiation exposure criteria which are applied for PCSB and reactor internal components and which determine the shielding requirements. Structural steel and weldments located in the lower plenum, where temperatures only slightly exceed $300^{\circ} \mathrm{C}$, must retain an end-of-life ductility of $10 \%$ based on total elongation [i.e., residual total elongation (RTE)]. The same 10\% RTE criterion is used for the core support system components. The total fluence 1 imit is about $10^{22} \mathrm{n} / \mathrm{cm}^{2}$.

The most severe component environment occurs in the upper plenum due to cooling with $550^{\circ} \mathrm{C}$ core outlet helium. Helium embrittlement is a primary concern for steel operating above $550^{\circ} \mathrm{C}$, and the irradiation effects data base is incomplete at high, exposures. Therefore, two stringent exposure criteria are applied to the upper plenum components: (1) total fluence of $1 \times 10^{21} \mathrm{n} / \mathrm{cm}^{2}$ and (2) helium concentration in steel of $\leq 1$ appm. The former 
UPPER PLENUM STRUCTURAL STEEL AND WELDMENTS AT $>550^{\circ} \mathrm{C}$ :

a) TOTAL FLUENCE $\leqslant 10^{21} \mathrm{n} / \mathrm{cm}^{2}$ b) HELIUM CONCENTRATION $\leqslant 1$ APPM

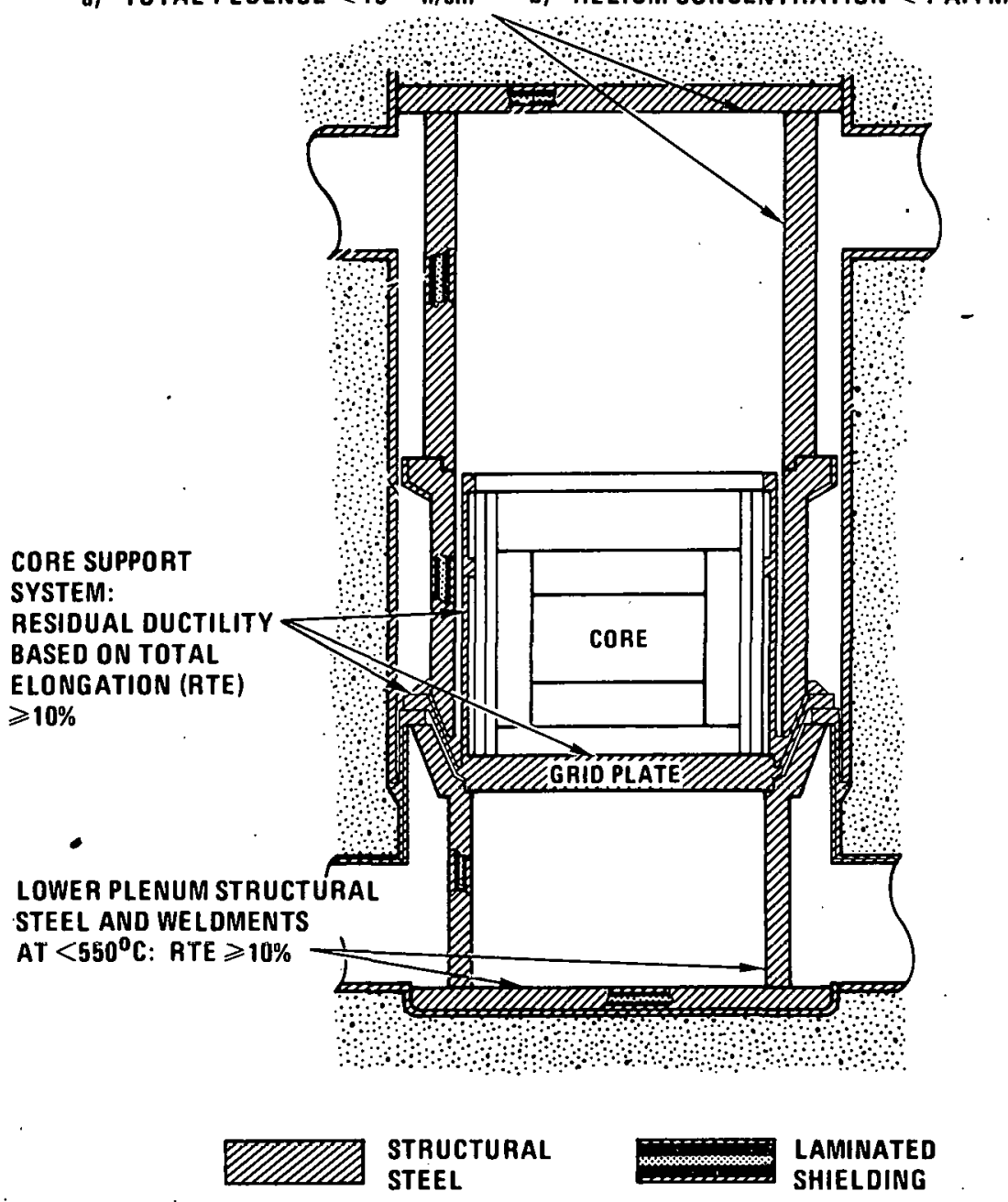

Fig. 2-3. Lifetime radiation exposure criteria for permanent GCFR structura1 steel. components 
limit was adopted from the LMFBR program, since high-temperature steel in the sodium-filled upper plenums of LMFBR systems does not receive exposures in excess of $10^{21} \mathrm{n} / \mathrm{cm}^{2}$. Ten percent RTE should be retained at these exposures.

Exposure to graphite and boronated graphite is kept below the leve1 where swelling occurs.

The PCSB components have stricter exposure limits. The steel components, such as the PCRV liner, rebar, cooling tubes, and longitudinal tendons, operate at temperatures as low as $100^{\circ} \mathrm{C}$. For these components, the nil ductility temperature shift, as defined by the Charpy notch test, is limited to $47^{\circ} \mathrm{C}$; this type of criteria is applied to light water reactor (LWR) pressure vessels. This limit corresponds to a total fluence of about $10^{19} \mathrm{n} / \mathrm{cm}^{2}$, using both damage function analysis and integral data correlations. Total fluence exposure to concrete is also limited to $10^{19} \mathrm{n} / \mathrm{cm}^{2}$. A limit of $10^{9}$ rad assures adequate corrosion protection by organic lubricant on the PCRV tendons.

Figure 2-4 shows the components of the GCFR shielding system (Ref. 8) which enable the exposure limits and various systems interface constraints to be met. The components are grouped into two subsystems:

1. A core shielding system protecting all the permanent internal components outside the core envelope, but inside the PCSB envelope.

2. An out-of-core internals shielding system protecting the PCSB.

The high power density core results in 30-yr total fluence levels exceeding $10^{23} \mathrm{n} / \mathrm{cm}^{2}$ at the outside of the blankets. Two rows of gridplate-supported replaceable reflector/shield assemblies provide attenuation in the radial direction, protecting the core restraint and permanent outer radial shield. Grid plate shields and exit shields are located within the 


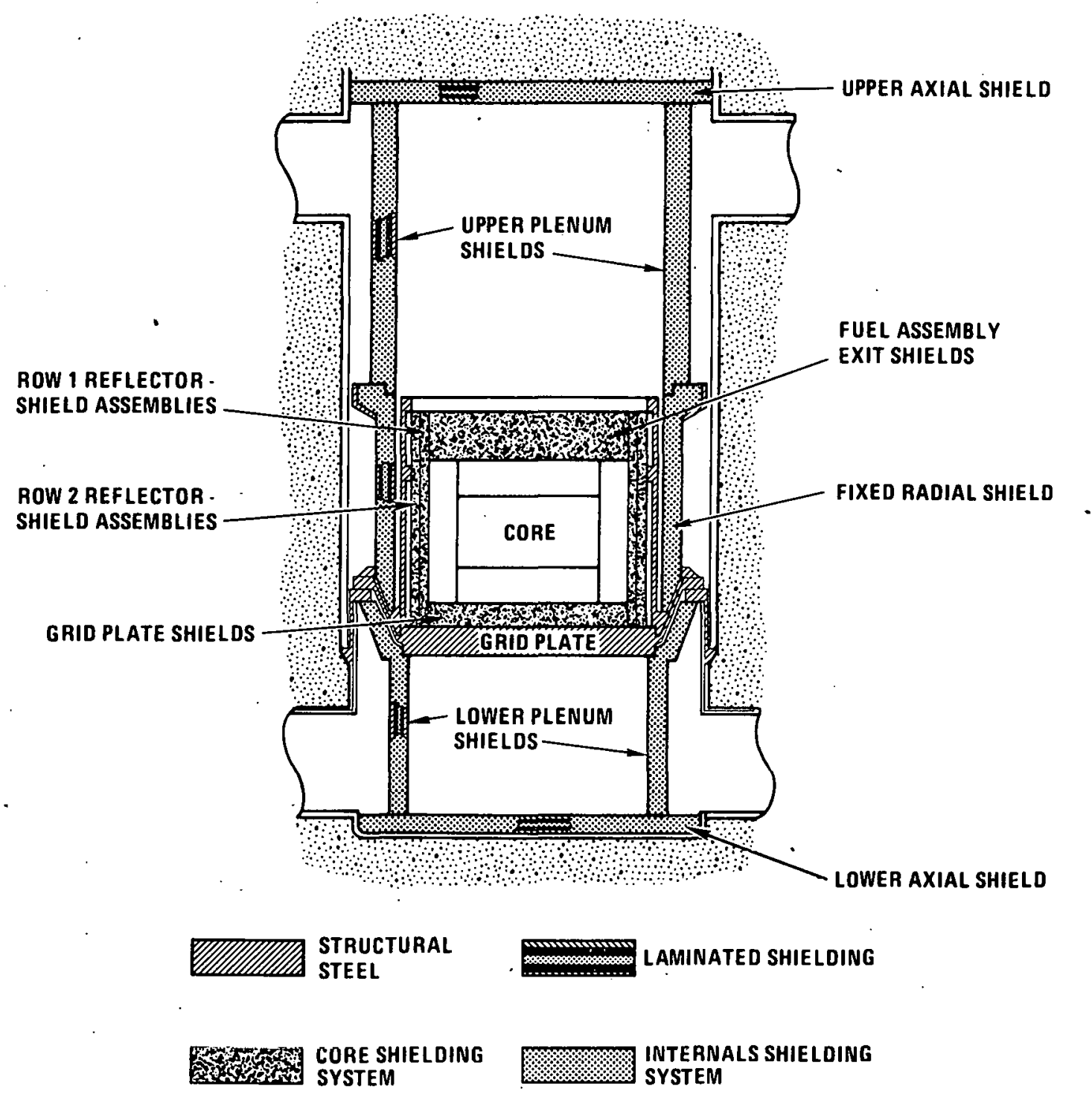

Fig. 2-4. GCFR shielding system components 
core assemblies inlet and outlet ends, respectively, protecting the permanent components in the upper and lower plenum. In a radial blanket management scheme, fuel assemblies are always loaded into the outer third row and subsequently shuffled to row 1 , then row 2 at 2 -yr intervals. This scheme is a compromise between reducing either shield thickness or peak radial blanket rod linear heat rate.

The internals shielding system consists of permanent upper and lower axial and radial shields and modular upper and lower plenum shields, which enable helium to flow to and from the ducts. All plenum shielding is laminated, consisting of layers of steel, graphite, and boronated graphite. Boronation is used extensively throughout this system to remove the low energy flux component which causes helium gas production in steel by the ( $n$, $\alpha$ ) reaction in $\mathrm{B}^{10}$, impurities, and the double nickel transmutation [ $\mathrm{Ni}^{58}$ $(n, \gamma) \mathrm{Ni}^{59}(\mathrm{~N}, \alpha) \mathrm{Fe}^{56}$ ].

Figure 2-5 shows the grid-plate-supported reflector/shield assemblies. Nineteen closely spaced steel clad shield rods containing either graphite or boronated graphite are contained within a hexogonal steel duct with the same outer dimensions as a fuel or blanket assembly. Graphite, an excellent reflector, is used to enhance breeding. Boron carbide in a graphite matrix is used in row 2 .

Figure 2-6 shows a fuel assembly with grid plate and exit shields. These shields, which are steel-clad natural boron carbide, are shaped to minimize helium pressure drop. Helium flow and shielding requirements always compete, and a strong incentive exists to minimize pressure drop to reduce circulator horsepower requirements. Streaming occurs in the helium coolant channels and gaps of the core and blankets. The core helium volume fraction is about 0.5 . The most effective method to calculate the core transport and streaming has been found to be two-dimensional biased quadrature discrete ordinates, where the core is modeled as alterating annular rings of helium, fuel, and steel. 

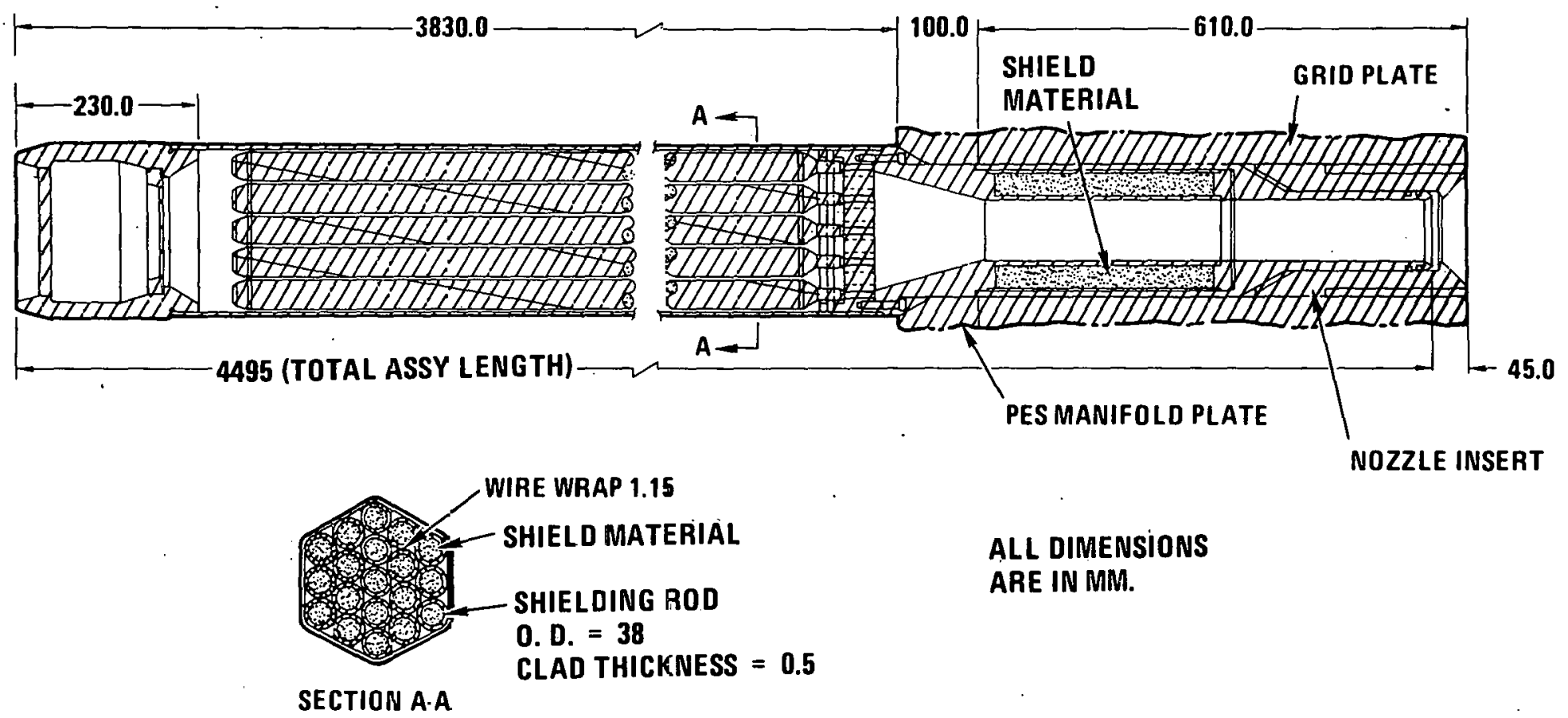

\section{ALL DIMENSIONS}

ARE IN MM.

SECTION A.A

Fig. 2-5. GCFR radial reflector shield assembly 


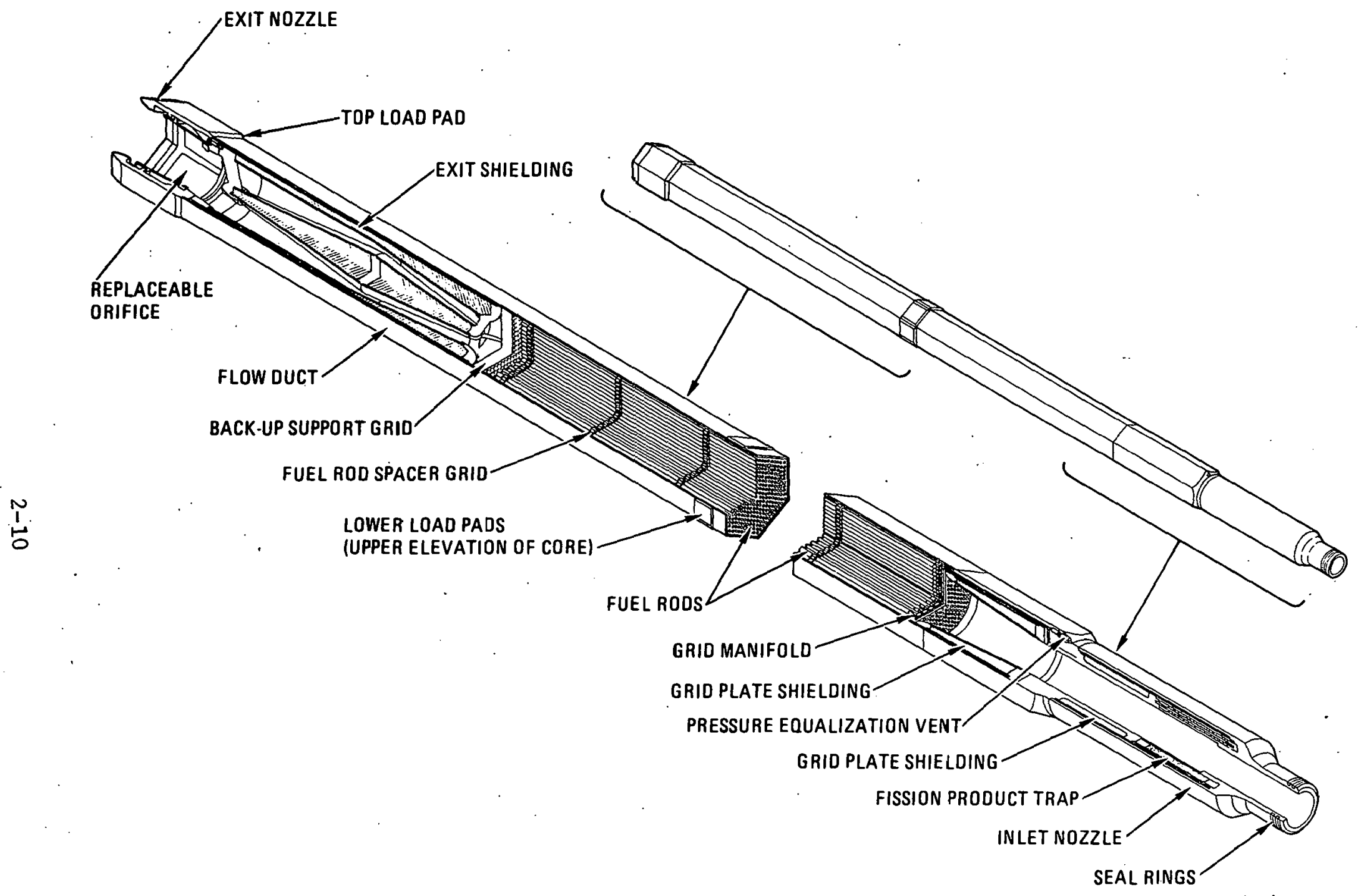

Fig. 2-6. GCFR upflow fuel assembly 
Figure 2-7 shows the grid plate shielding (Ref. 9) in more detail. This shielding provides integumental or local protection of the grid plate. A hexagonal shield is between the axial blanket and the grid plate, and an annular shield is within the grid plate hole.

Figure 2-8 shows a detailed drawing of the fuel assembly exit shields. Coolant gas passes through the annular duct surrounded on both sides with neutron absorbers. The coolant path is angled slightly to prevent neutron streaming. Preliminary calculations show that neutron fluence is reduced by a factor of about 600 with this exit shield design.

Figure 2-9 is a drawing of the control assembly; the exit shield is shown at the top of the page. The control assembly exit shield consists of two parts, as shown in the center section $B-B$ at the bottom of the drawing. The outer part of the shield $\left(B_{4} C\right)$ is fixed to the outer surface of the assembly. The central part of the shield $\left(B_{4} C\right)$ surrounds the control rod and moves with it. The lower half of the top figure shows the control rod in the fully inserted position; the upper half of the figure shows the fully withdrawn position.

Figure 2-10 shows a horizontal cut through several candidate plenum shield concepts. These shields must allow to flow to and from the helium ducts with minimum pressure drop and flow direction change so that the onset or effectiveness of free convection core cooling is not delayed during emergency loss of flow conditions. The concept, called the herringbone design, provides three changes in streaming and flow direction. Two variations of the chevron design provide a smooth curved flow and streaming path. All of the large internal shields are laminated; an outer steel casing contains steel-clad bricks of boronated graphite and graphite.

After careful consideration of the relative shielding effectiveness (ORNL calculations), relative pressure drops, relative stiffness, and 


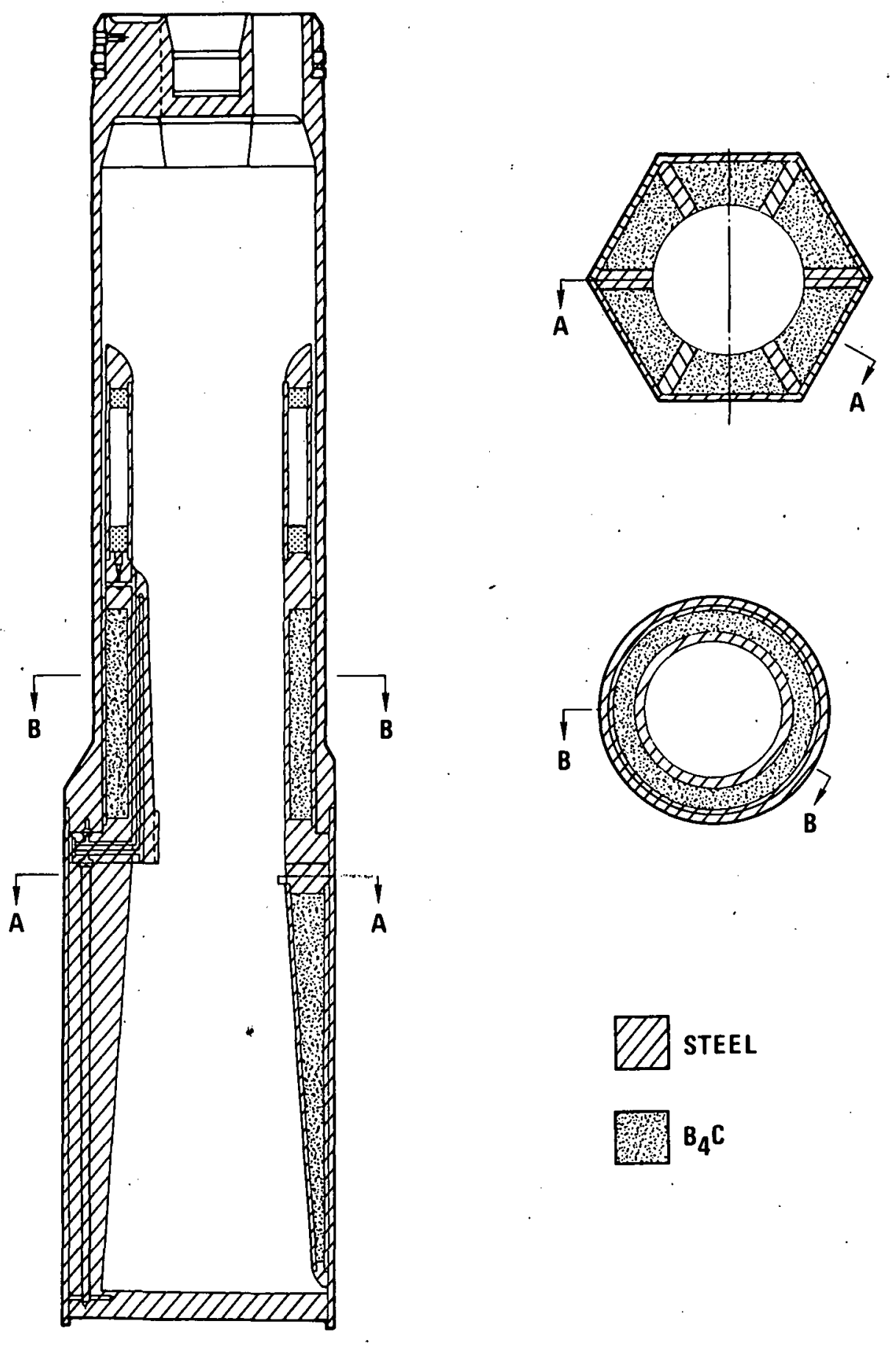

Fig. 2-7. GCFR grid plate shielding 


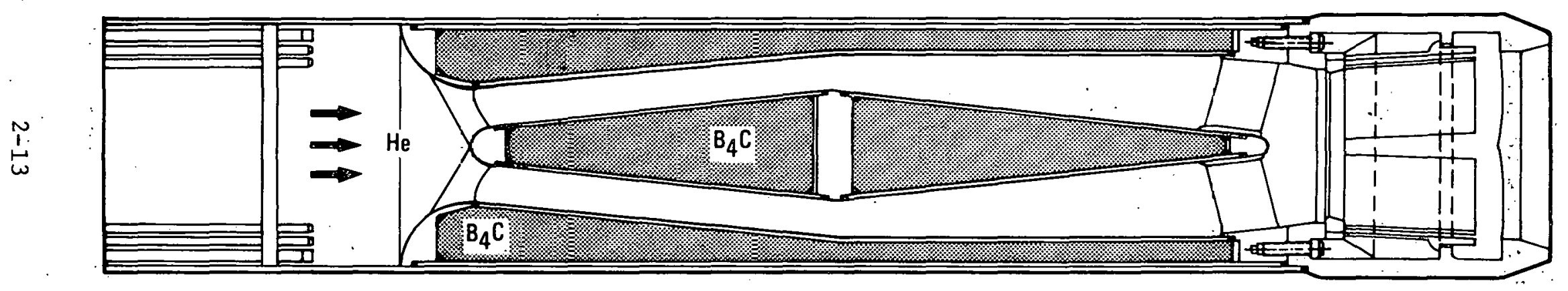

Fig. 2-8. Fueil assembly exit shields 
relative costs of construction, the following flow-through shields were chosen:

1. Upper plenum $=45.72 \mathrm{~cm}$ (18 in.) chevron with a $5.08 \mathrm{~cm}$ (2 in.) gap.

2. Lower plenum $=53.34 \mathrm{~cm}(21 \mathrm{in.})$ chevron with a $7.62 \mathrm{~cm}$ (3 in.) gap.

This experiment will test the accuracies of the theoretical flux reduction factors of 37 and 63 for the upper and lower plenums, respectively. 


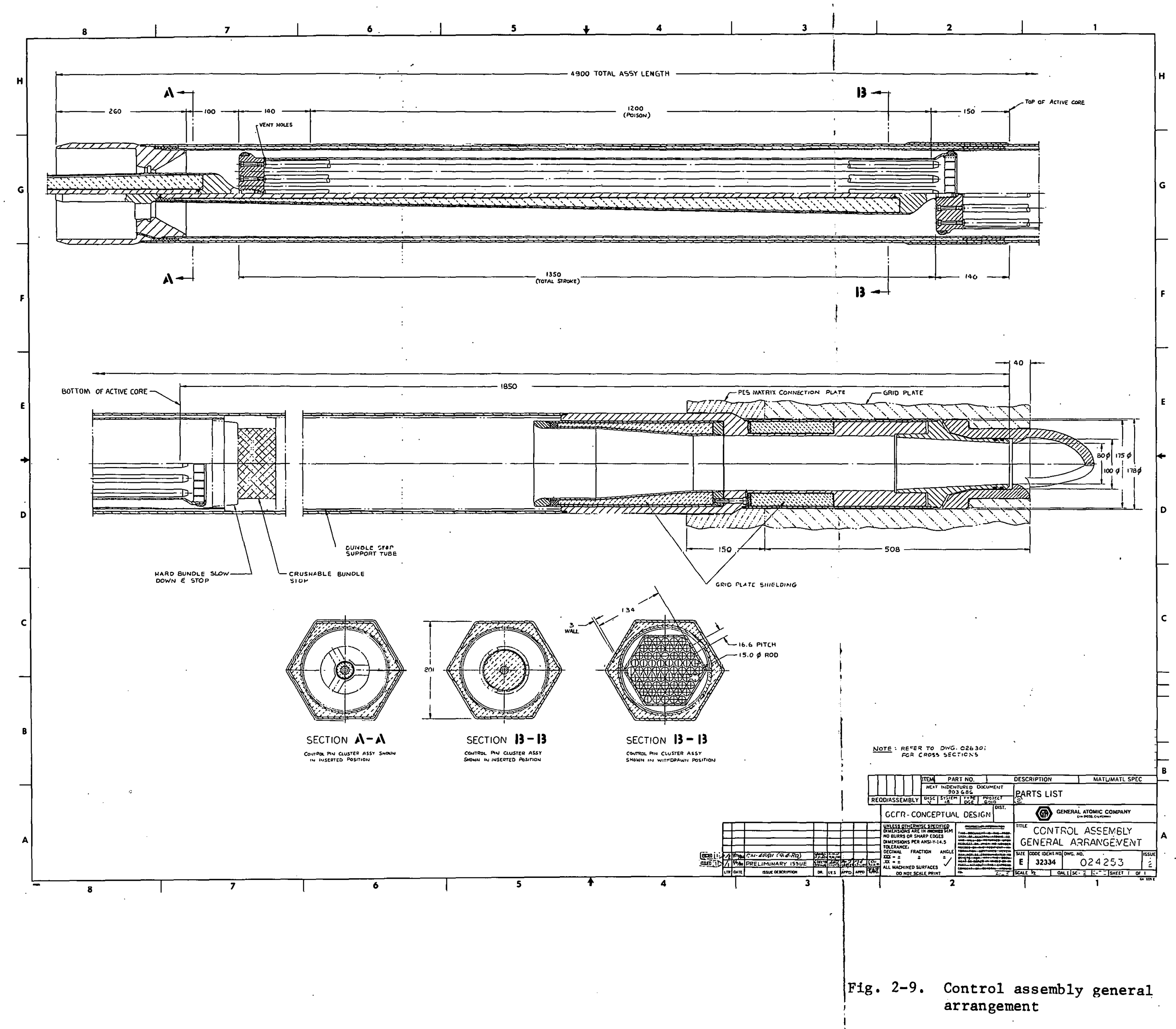




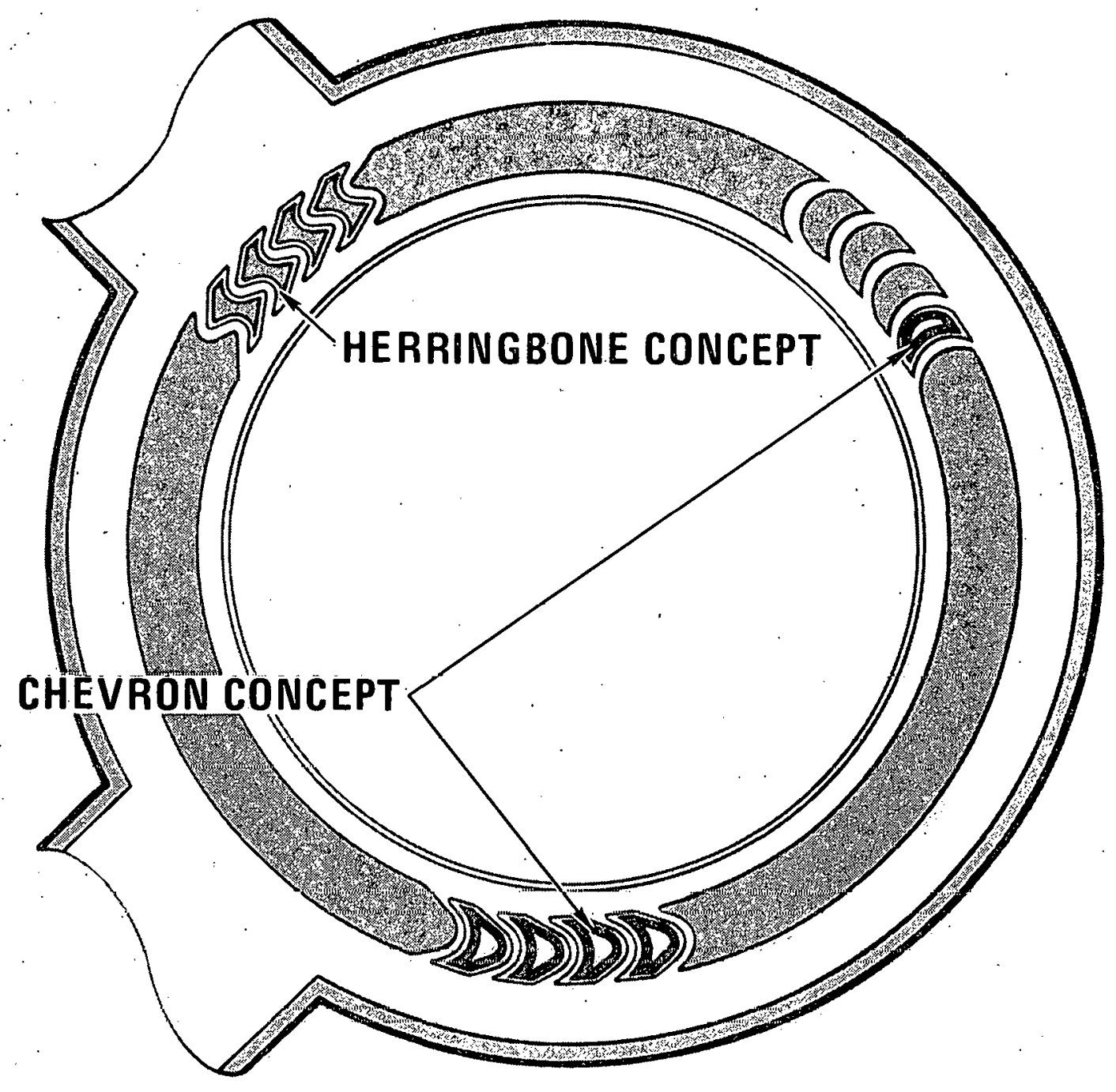

Fig. 2-10. Horizontal cut through reactor plenum showing flow-through plenum shield concepts 
,

$2-18$ 


\section{EXPERIMENT OBJECTIVES}

As discussed in Section 2, the shielding, structures, and ducts which comprise the upper and lower plenums in the GCFR are regions of geometric complexity. Four categories of uncertainties exist in computing exposure levels of the GCFR plenum components:

1. Uncertainties in streaming in the coolant channels between the core and blanket rods and fuel assemblies and streaming in the grid plate and exit shield regions.

2. Uncertainties in neutron and gamma-ray streaming and scattering in the geometrically complex and sometimes large helium ducts, channels, and plenums.

3. Uncertainties in transport to deep penetration through successive thicknesses of laminated shielding and PCRV concrete.

4. Uncertainties in transport through the laminated shielding due to the complex helium flow channels and manufacturing construction. gaps and tolerances.

Since streaming within the core and core shielding affects the leakage sources into the plenums and plenum streaming affects the source incident on the large shield structures, uncertainties in each category become additive. The GCFR grid plate shield design confirmation experiment addressed the core and grid plate streaming. The GCFR radial blanket and shield experiment addressed category 3 (above): The overall objective of the plenum streaming experiment is to quantify exit shield transport uncertainties and plenum 
streaming and scattering uncertainties, including the heterogeneous nature of the plenum shields. An experiment cannot simultaneously quantify all. uncertainties, because a nearly full-scale mockup of the core plenums and ducts would be required. 


\section{TEST REQUIREMENTS}

\subsection{TECHNICAL PRODUCTS.}

The objective of the plenum streaming experiment is to provide two technical products: (1) experimental methods and data benchmark problems and (2) radiation transmission, heating, and spectrum bias factors to apply in actual design calculations.

The benchmark problems enable the General Atomic (GA) and ORNL design analyses methods and data to be compared. The benchmark problems also provide a vehicle for developing and/or checking new methods and data.

Sensitivity analysis defines sources of errors in calculating the experiment, yielding the bias factors. When the experimental environment is prototypical of the reactor environment, experimental results can be extrapolated with greater confidence to obtain design analyses bias factors.

\section{4. ?. FXPERIMENT PHASES}

Section 3 described the four categories of uncertainty associated with calculating transport from the core to the plenums, and ultimately to the primary coolant system boundary, viz.,

1. Shield heterogeneity.

2. Exit shield simulation (core and exit shield streaming).

3. Plenum streaming (and scattering).

4. Plenum shield simulation (deep penetration).

Each phase has independent test sections and measurement definitions to quantify each uncertainty category. 


\subsubsection{Shield Heterogeneity Phase}

The large laminated shield structures in the upper and lower plenums will be far from homogeneous laminated layers. Heterogeneities will result due to the following:

1. Helium gaps within and between shield assembly components which result from manufacturing and construction tolerances, thermal expansion, and radiation-induced dimension changes in the shield materials.

2. Heterogeneities resulting from the steel encasement of the graphite and boronated graphite shield materials (e.g., enhanced transport in the low cross, section windows of steel).

The effects of the shield heterogeneities are not considered significant enough to necessitate a prototypical mockup of the shield assemblies. Rather, a more generic mockup of helium and/or steel gaps will validate transport methods for the expected range of gaps. The measurement results are expected to guide the setting of tolerances during fabrication and assembly of the shielding assemblies.

The basic test section arrangement is identical to the slab arrangement used for the radial shield experiment, except that the heterogeneity mockup is the next to the last slab.

Table 4-1 gives the measurement configuration matrix for the shield heterogeneity phase. The gap types and sizes span a range expected for GCFR reflector/shield assemblies, outer radial shield modules, and even the plenum shield modules. Figures 4-1 through 4-4 show the four shield heterogeneity phase configurations. The following horizontal traverse measurements will be performed for each configuration:

1. Hornyak button $[0.635 \mathrm{~cm}(1 / 4 \mathrm{in.})]$ at $0 \mathrm{~cm}$ (close as possible) and at $30.5 \mathrm{~cm}(12 \mathrm{in.})$. 
TABLE 4-1

MEASUREMENT CONFIGURATION MATRIX FOR THE SHIELD HETEROGENEITY PHASE

\begin{tabular}{|c|c|c|c|c|c|c|c|}
\hline & \multirow[b]{2}{*}{ Configuration } & \multicolumn{6}{|c|}{ Gap Size } \\
\hline & & $\begin{array}{l}0.635 \mathrm{~cm} \\
(1 / 4 \mathrm{in.})\end{array}$ & $\begin{array}{l}1.27 \mathrm{~cm} \\
(1 / 2 \mathrm{in.})\end{array}$ & $\begin{array}{l}2.54 \mathrm{~cm} \\
(1 \mathrm{in.})\end{array}$ & $\begin{array}{l}5.08 \mathrm{~cm} \\
(2 \mathrm{in} .)\end{array}$ & $\begin{array}{l}7.62 \mathrm{~cm} \\
(3 \mathrm{in.})\end{array}$ & $\begin{array}{r}10.16 \mathrm{~cm} \\
(4 \mathrm{in.})\end{array}$ \\
\hline I. & $\begin{array}{l}\text { All graphite with } \\
\text { one vertical gap }\end{array}$ & $\mathrm{x}$ & $\mathrm{x}$ & $\mathrm{x}$ & $\mathrm{X}$ & $\mathrm{x}$ & $\mathrm{X}$ \\
\hline II. & $\begin{array}{l}\text { Graphite with steel } \\
\text { slaps and one } \\
\text { vertical gap }\end{array}$ & $\mathrm{x}$ & $\mathrm{x}$ & $\mathrm{x}$ & . & & \\
\hline III. & $\begin{array}{l}\text { Graphite with steel } \\
\text { slabs and three } \\
\text { vertical gaps }\end{array}$ & $\mathrm{x}$ & $\mathrm{x}$ & $\mathrm{x}$ & & . & \\
\hline IV. & $\begin{array}{l}\text { Braphite with one } \\
\text { offset gap }\end{array}$ & $\mathrm{x}$ & & $\mathrm{x}$ & $x$ & $\mathrm{X}$ & $x$ \\
\hline
\end{tabular}




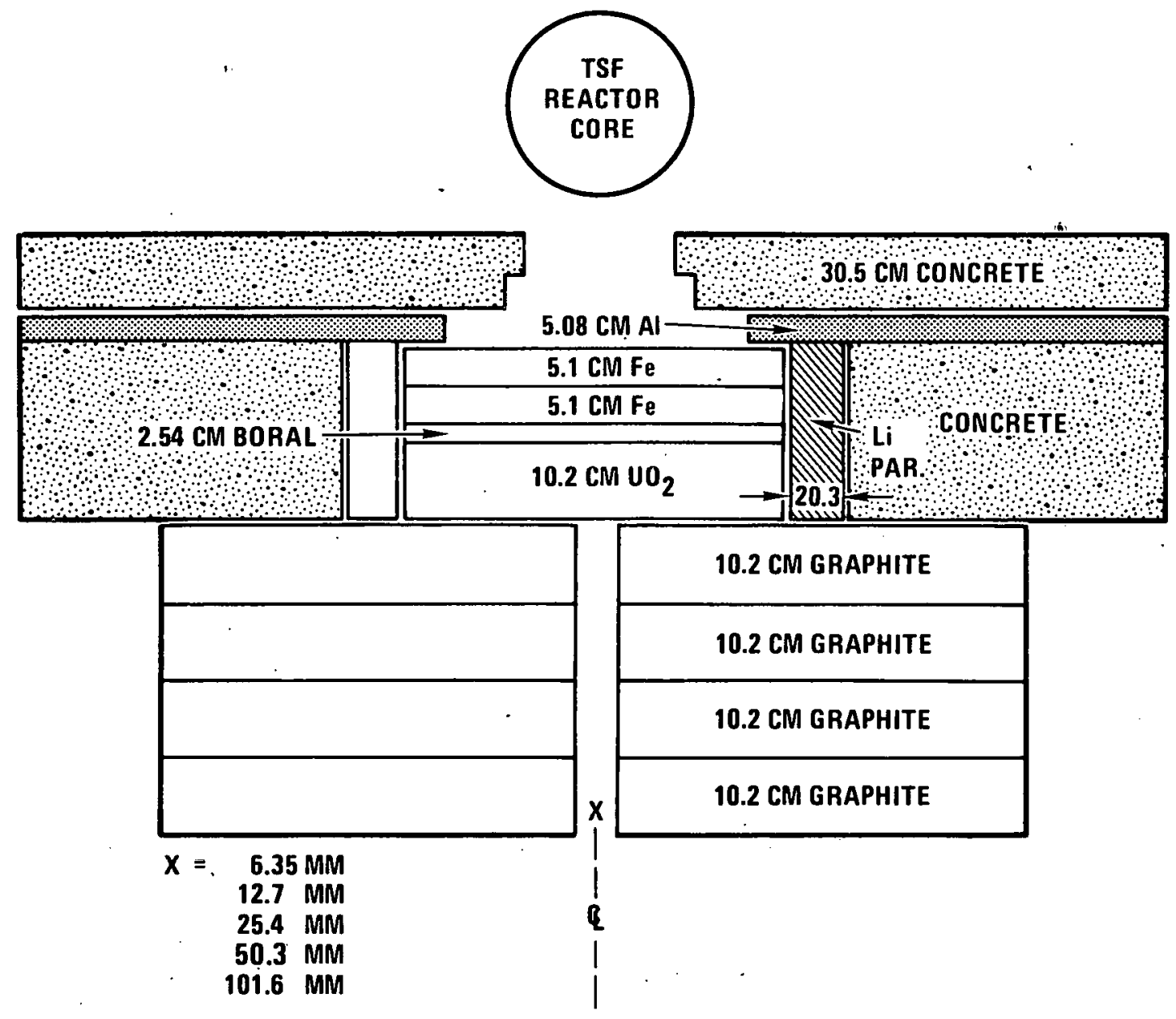

Fig. 4-1. Configuration I: all.graphite 


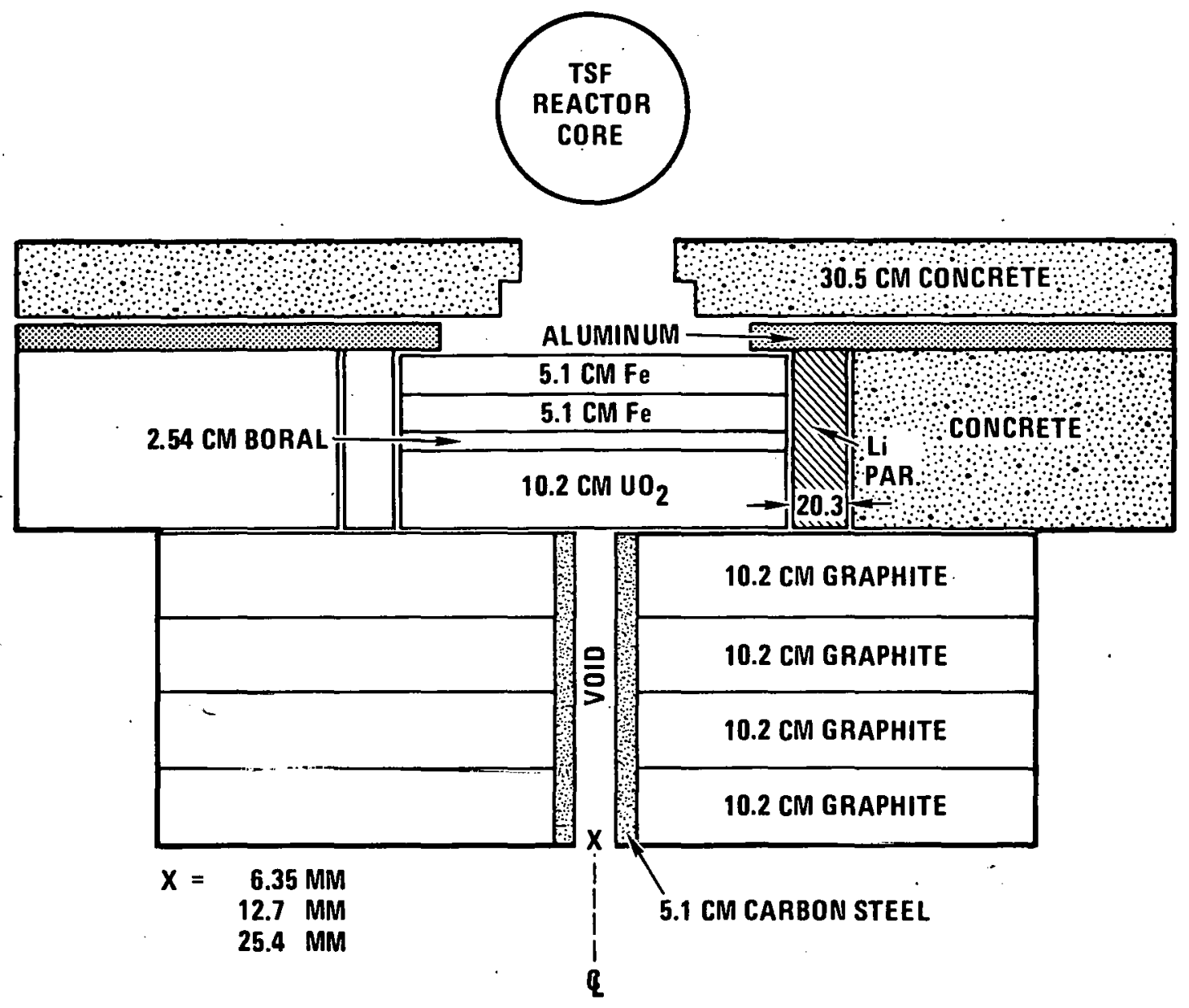

Fig. 4-2. Configuration II: carbon steel and graphite, single gap 

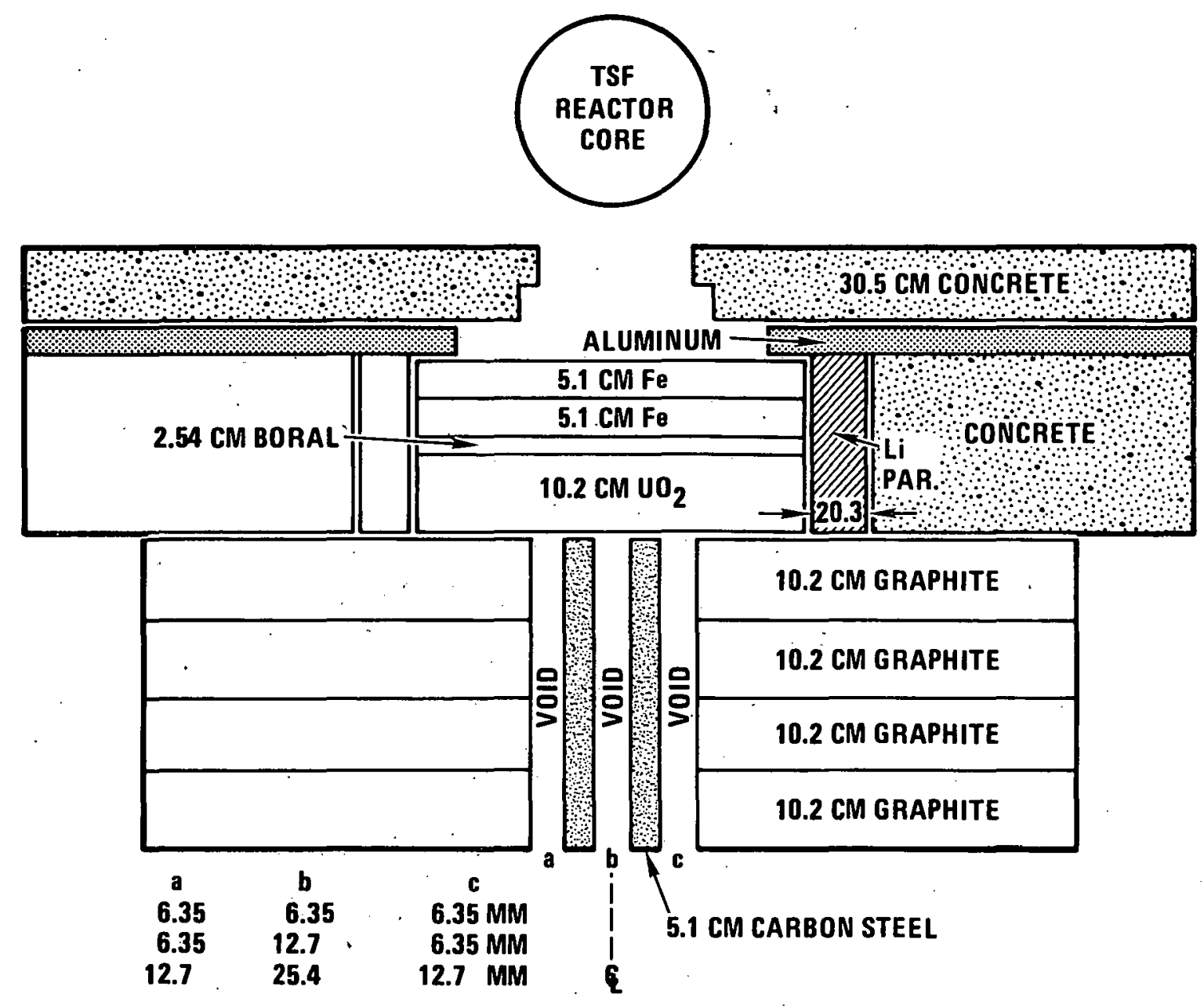

Fig. 4-3. Configuration III: carbon steel and graphite, three gaps 


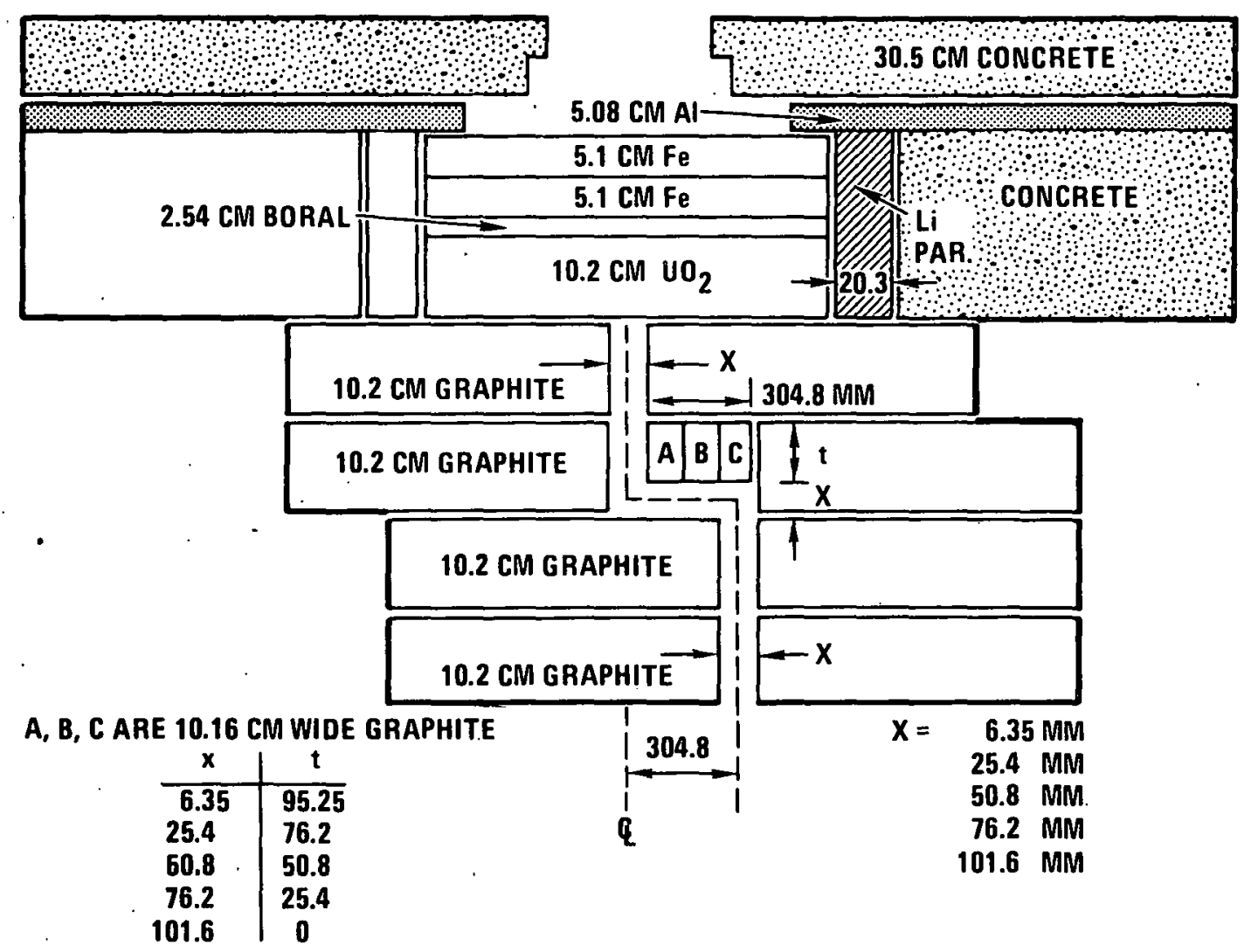

Fig. 4-4. Configuration IV: graphite offset gap 
2. 5.08-cm (2-in.) cadmium-covered Bonner ball at $0 \mathrm{~cm}$ (close as

- possible).

3. 5.08-, 12.7-, and 25.4-cm (2-, 5-, and 10-in.) Bonner balls at $30.5 \mathrm{~cm}$ (12 in.).

The Hornyak button measurements are to obtain local flux peaking profiles and the $5.08-\mathrm{cm}$ (2-in.) cadmium-covered Bonner ball measurements at $0 \mathrm{~cm}$ are for absolute flux normalization. The 5.08-, 12.7-, and $25.4-\mathrm{cm}$ (2-, 5-, and 10-in.) Bonner balls will yield sufficient spectral data. Heterogeneity phase measurements began in April 1980.

\subsubsection{Exit Shield Simulation Phase}

This experiment addresses the combined effects of streaming in the core, axial blankets, and fuel assembly exit shields. The experimental configuration is identical to that used for the GCFR grid plate design. confirmation experiment, except that grid plate shield mockups are replaced with exit shield mockups; control rod position is also a primary measurement parameter.

The importance of including control rod effects with control rod position as a variable is apparent from results of transport analysis. Calculations were performed for seven assembly cells with one dedicated central control assembly and six adjacent fuel assemblies. In one case, a control rod bundle was fully inserted, and in the other case, fully withdrawn. Figures 4-5 through 4-7 show $R-Z$ models for the two cases.

Figures 4-8 and 4-9 show total isofluence plots ( $>0.0 \mathrm{MeV}$ ) for 30 effective power years (EPY) at 0.75 capacity factor for the two cases. Table 4-2 gives total fluence values at four important locations, numbered in Fig. 4-6. Compared to the fully inserted rod position, complete withdrawal of the dedicated control decreased the flux at the control assembly exit end by about a factor of 80 . However, with the rod fully inserted, the 


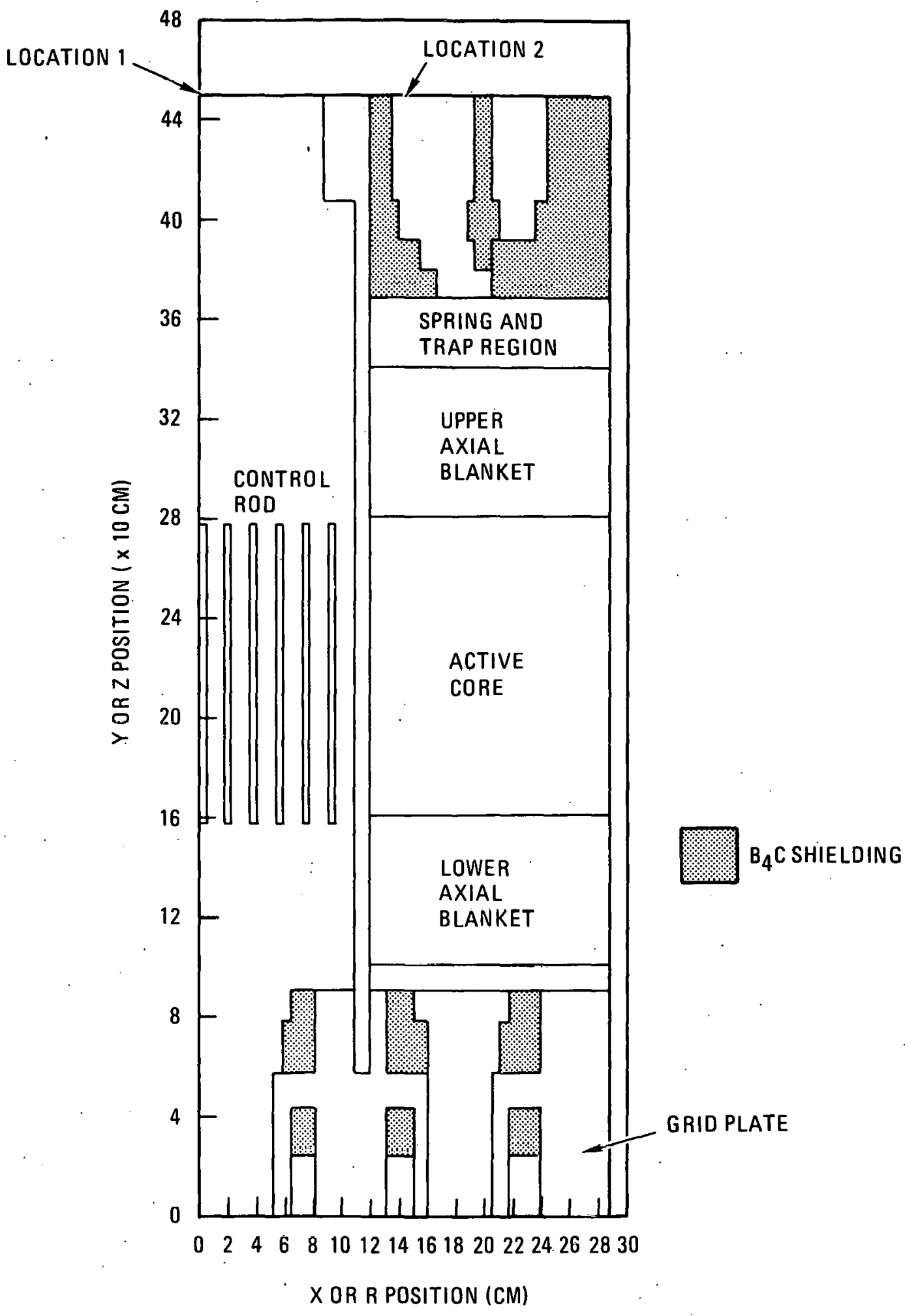

F1g. 4-5. DOT IV R-Z model of seven assembly cell with central control $\checkmark$ rod fully inserted 


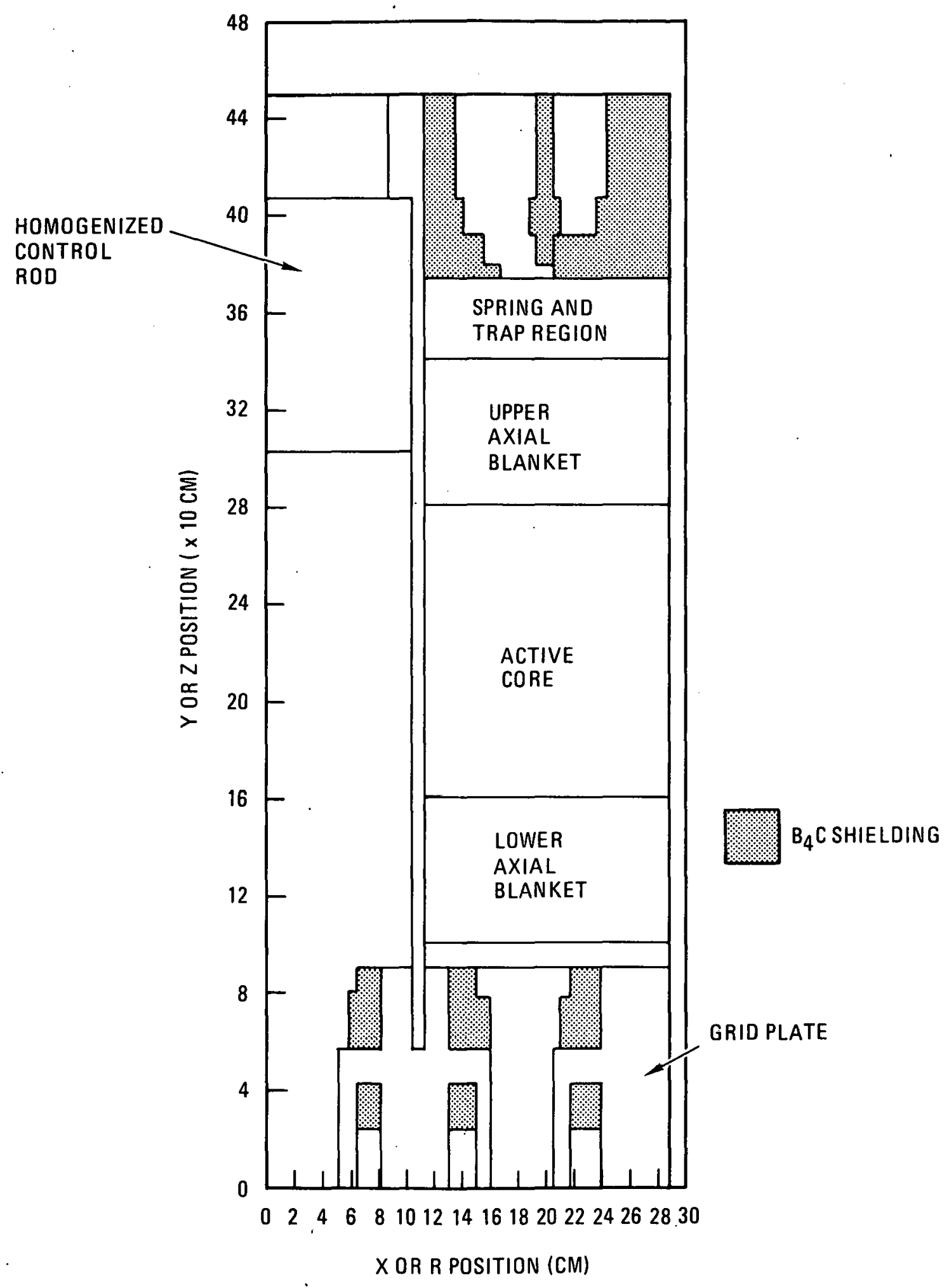

Fig. 4-6. DOT IV R-Z model of seven assembly cell with central control rod fully withdrawn 


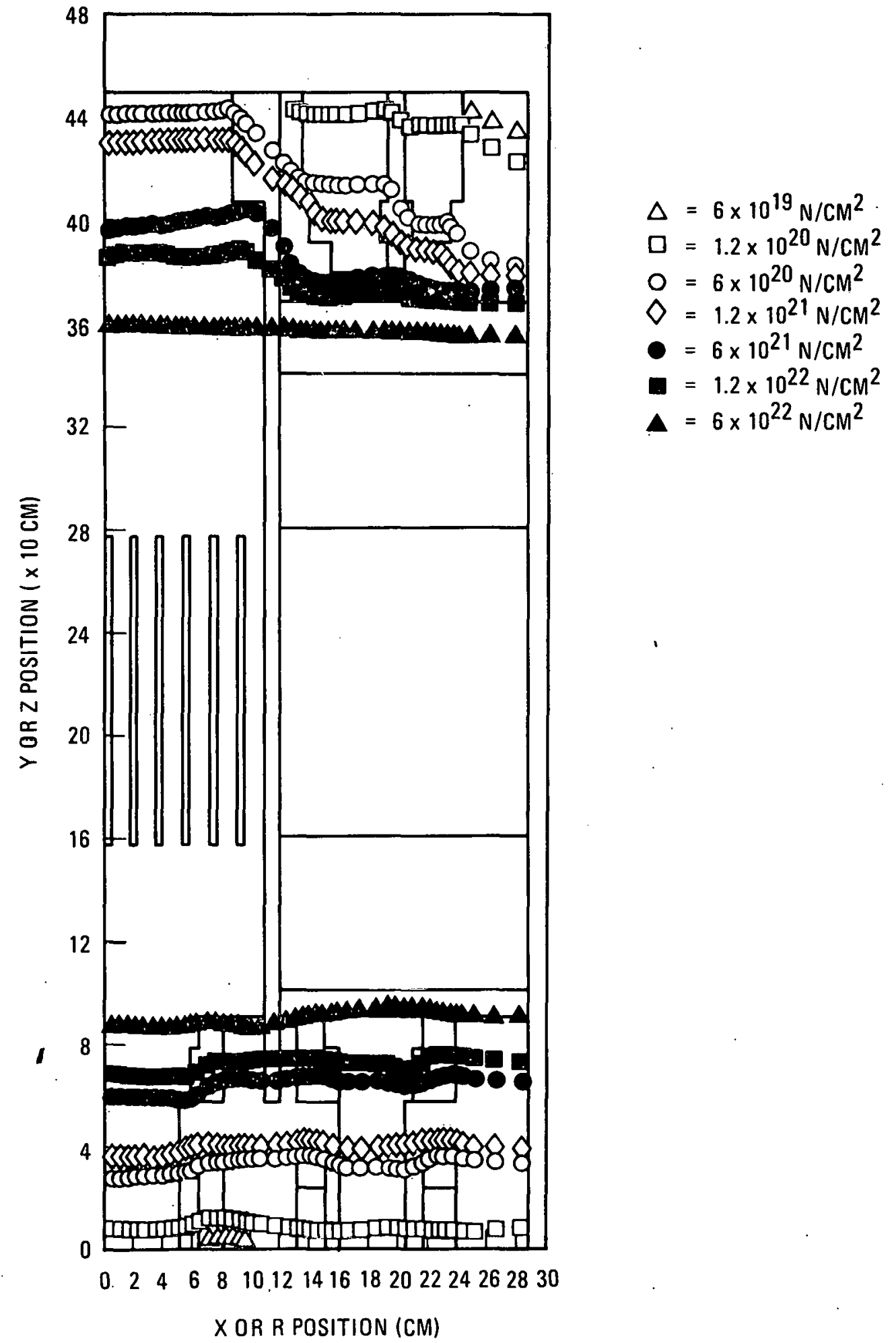

Fig. 4-7. Total 30-EPY fluence with control rod inserted 


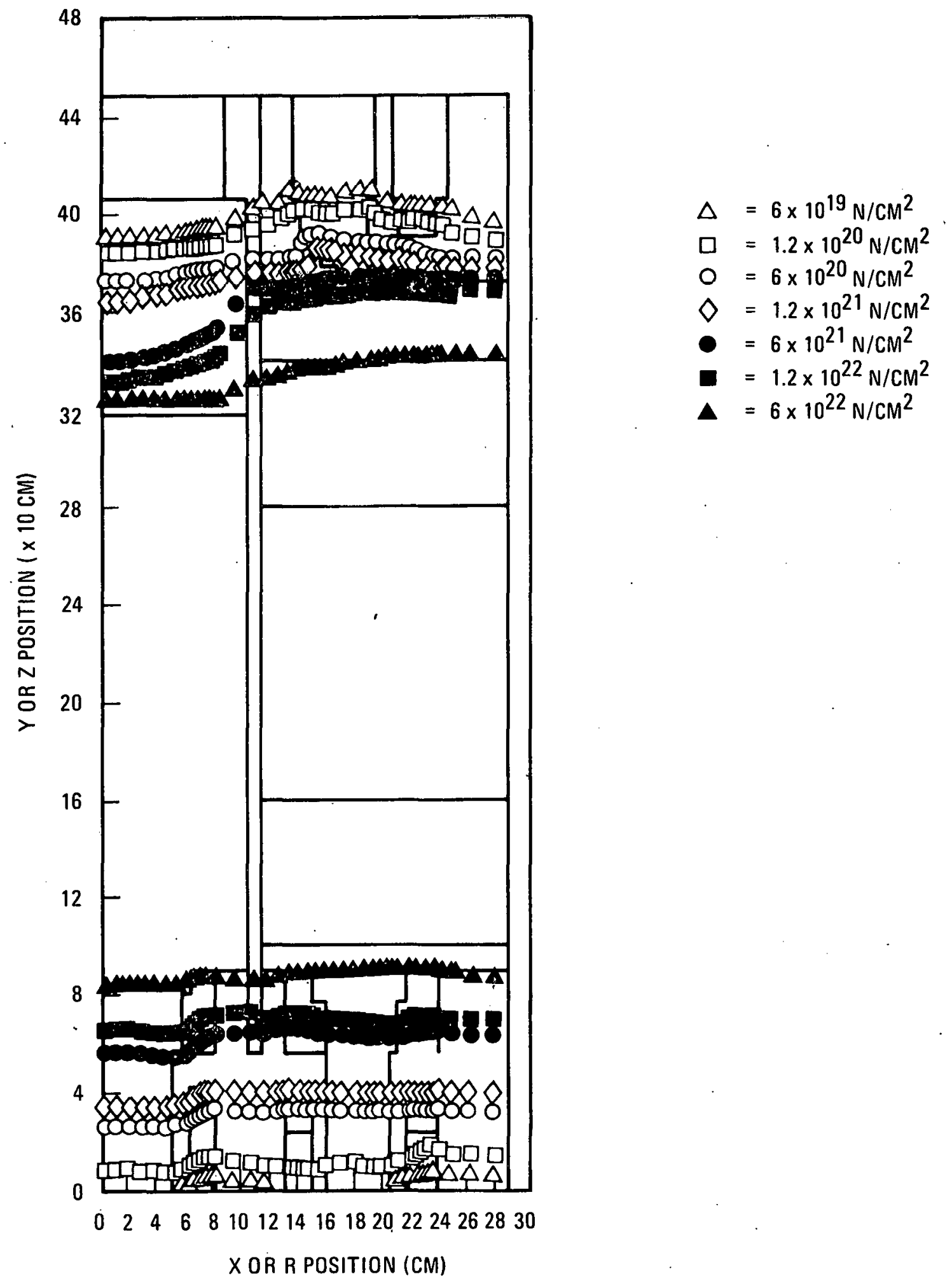

Fig. 4-8. Total 30-EPY fluence with control rod withdrawn 


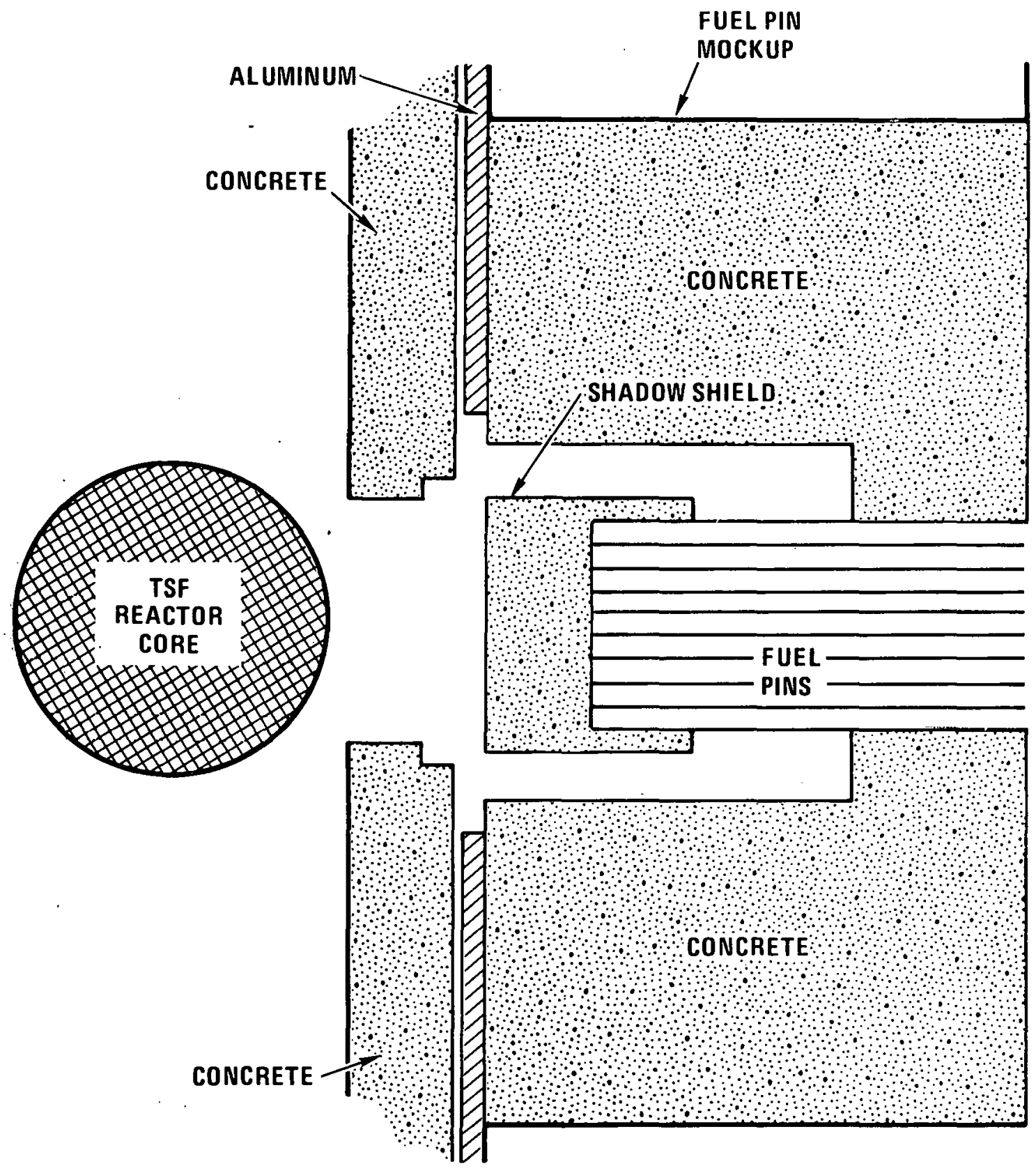

F1.g. 4-9. Configuration I: seven fuel assemblies 
TABLE 4-2

TOTAL 30-EPY FLUENCE AT IMPORTANT LOCATIONS

\begin{tabular}{|c|c|c|c|}
\hline \multirow[b]{2}{*}{. } & \multirow[b]{2}{*}{ Location } & \multicolumn{2}{|c|}{30 EPY Total Neutron Fluence $\mathrm{n} / \mathrm{cm}^{2}$} \\
\hline & & $\begin{array}{c}\text { Control Rod Fully } \\
\text { Withdrawn }\end{array}$ & $\begin{array}{l}\text { Control Rod Fully } \\
\text { Inserted }\end{array}$ \\
\hline & $\begin{array}{l}\text { Control assembly exit end on } \\
\text { center line }\end{array}$ & $6.1 \times 10^{18}$ & $4.8 \times 10^{20}$ \\
\hline & $\begin{array}{l}\text { Peak at fuel assemblies exit } \\
\text { end }\end{array}$ & $4.3 \times 10^{18}$ & $8.7 \times 10^{19}$ \\
\hline
\end{tabular}


flux at the control assembly exit end was a factor of five greater than at the exit of the adjacent fuel assemblies.

The control rod composition in the control assembly mockup needed to be determined early in preanalysis. The experimental mockup differs from the GCFR core in that the neutron multiplications are due to low energy neutrons. Insertion of the control assembly mockup into the lattice was suspected to significantly reduce the fission source magnitude and greatly perturb the source spatial distribution. The changes (reducing the source and perturbing the spacial distribution) are dependent upon the $\mathrm{B}_{4} \mathrm{C}$ control rod content. ORNL initiated DOT calculations to determine the proper graphite or $\mathrm{B}_{4} \mathrm{C}$ loading to best simulate GCFR core conditions. Table 4-3 shows the total fission source for several experimental configurations calculated with DOT-IV.

Table 4-3 shows that removing the central fuel assembly reduces the total source by only about $8 \%$. Half insertion of the $\mathrm{B}_{4} \mathrm{C}$ control rod (worst case) reduced the source an additional. $8 \%$.

Table 4-4 compares a $\mathrm{B}_{4} \mathrm{C}$ control rod mockup to the graphite control rod mockup for the GCFR; these results indicate that the $\mathrm{B}_{4} \mathrm{C}$ control rod should be selected. The $\mathrm{B}_{4} \mathrm{C}$ rod results in a larger flux depression at the assembly exit end than the graphite rod. The exit end flux depression due to a withdrawn control rod is less in the experimental mockup than in the GCFR due to the side in-leakage from the concrete in the experimental mockup.

Table 4-5 shows the measurement configuration matrix for the exit shield simulation phase.

Figure 4-8 is a schematic of configuration $I$, consisting of seven fuel assemblies with no exit shields. For configuration I, all materiáls are from the grid plate shield experiment and have already been measured. For configuration II (Fig. 4-1.0), crsit ehield modules are added to all seven fuel assemblies. 
TABLE $4-3$

TOTAL FISSION SOURCE FOR SEVERAL EXPERIMENTAL CONFIGURATIONS

\begin{tabular}{l|c}
\hline \multicolumn{1}{c|}{ Configurations } & Total Fission Source \\
\hline 7 fuel assemblies & $2.6 \times 10^{9}$ \\
6 fuel assemblies and \\
empty central assembly \\
6 fuel assemblies with \\
$\begin{array}{l}\text { B C control rod half } \\
\text { inserted } \\
\begin{array}{l}6 \text { fuel assemblies with } \\
\text { graphite control rod } \\
\text { half inserted }\end{array}\end{array}$ \\
\hline
\end{tabular}


TABLE $4-4$

COMPARISON OF CONTROL ROD MOCKUP WITH $\mathrm{B}_{4} \mathrm{C}$ AND GRAPHITE

\begin{tabular}{l|c|c|c}
\hline & $\begin{array}{c}\text { Decrease in Flux at } \\
\text { Assembly Exit End with Rod } \\
\text { Fully Withdrawn Compared } \\
\text { With Fully Inserted }\end{array}$ & $\begin{array}{l}\text { Ratio of Flux at } \\
\text { Contro1 Assembly } \\
\text { Exlt End to Flux } \\
\text { at Fuel Assembly } \\
\text { Assembly Exit End }\end{array}$ \\
\cline { 2 - 4 } & Control Assembly & Fuel Assembly & 5 \\
\hline $\begin{array}{l}\text { GCFR } \\
\text { B } 4 \text { C control rod }\end{array}$ & 80 & 20 & 7 \\
$\begin{array}{l}\text { Experiment with } \\
\text { graphite control rod }\end{array}$ & 12 & 3 & 8 \\
\hline
\end{tabular}


TABLE 4-5

MEASUREMENT CONFIGURATION MATRIX FOR THE EXIT SHIELD PHASE

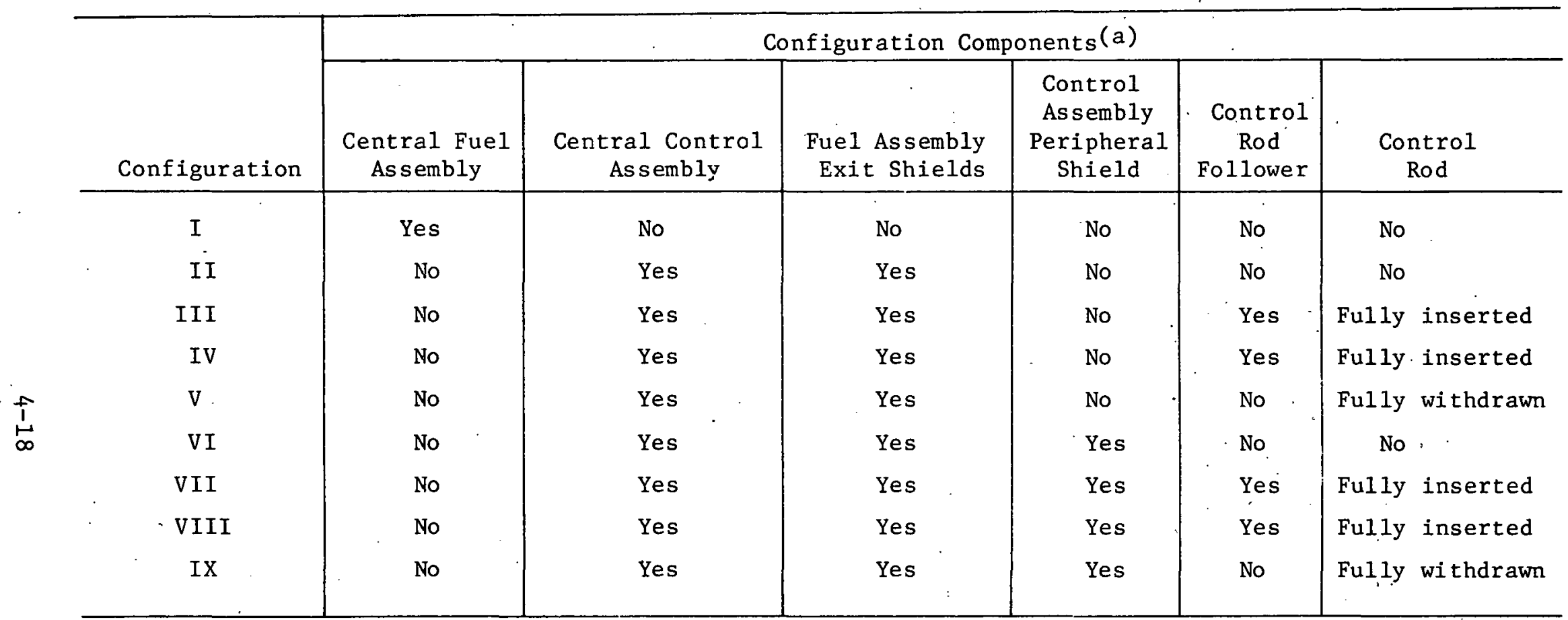

(a) Configuration components include six fuel assemblies and the components listed. 


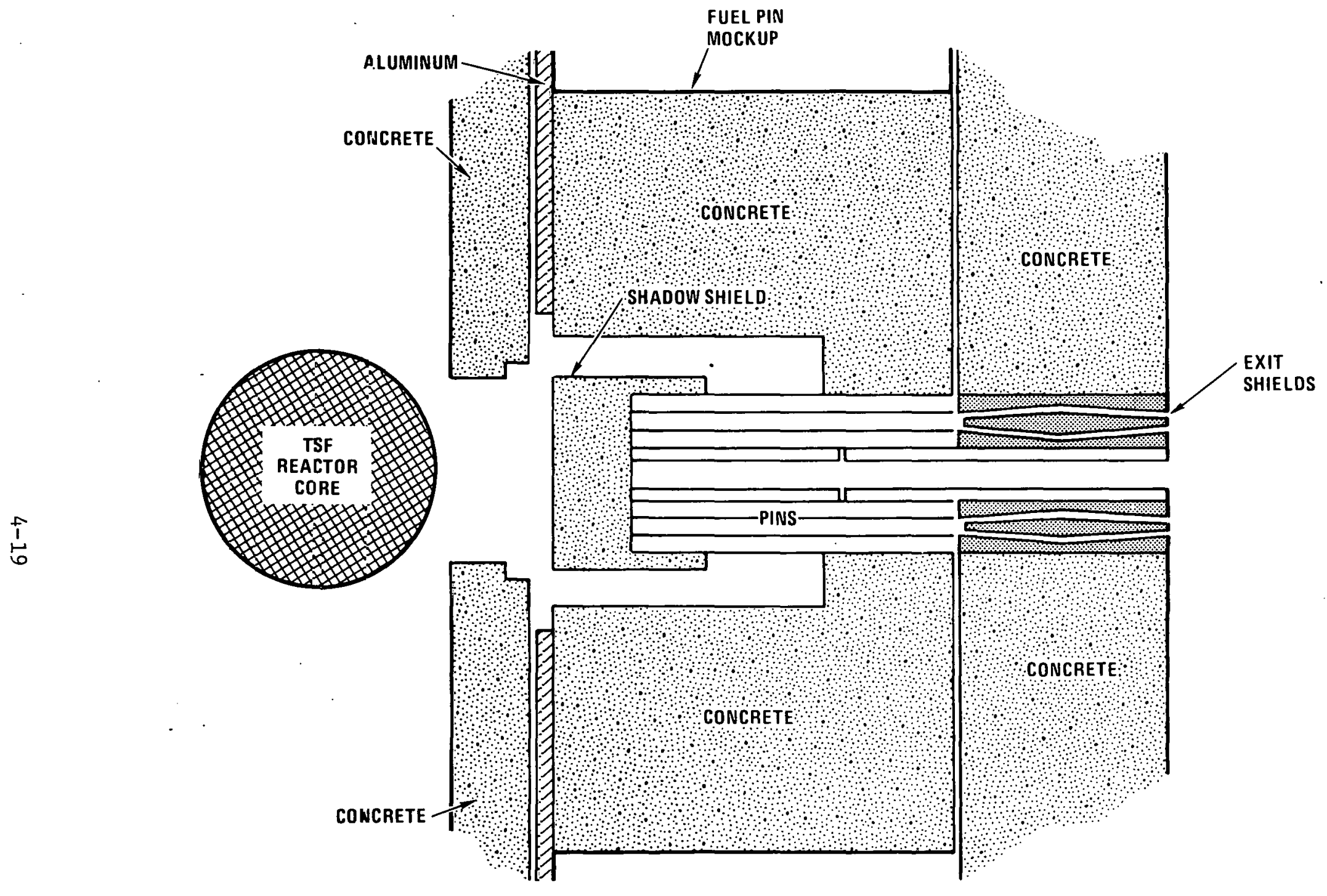
Fig. 4-10. Configuration II: seven fuel assemblies [nine rods per assembly, 0.635 (1/4-in.) duct
gap] with exit shields and no control rod 
Configurations III through IX, shown in Figs: 4-11 through 4-17, respectively, are all control assembly mockups. The measurement matrix shows that a set of three measurements (control rod fully inserted, half inserted, and fully withdrawn) are done with and without the peripheral control assembly shields. Thus, the peripheral shield effectiveness can be directly measured. The relative effectiveness of the peripheral shields and the control rod follower will also be obtained.

Fuel rod pitch and interassembly duct gap spacing need not be considered as parameters, since the grid plate shield experiment provides sufficient data to enable interpolation over the range of expected core parameters. The selected configuration includes 91 rods per assembly and a $1.27-\mathrm{cm}(1 / 2-i n$.$) duct gap, which best approximates the current design for$ the 400-MW(e) two-loop GCFR demonstration plant.

The grid plate shield design confirmation experiment emphasized measuring the local grid plate exposure, especially local flux peaking by traverse measurements with small Hornyak button scintillation detectors. The exit shield phase will also measure local flux peaking. However, the experiment will also emphasize global flux measurements, because calculations of the source to the upper plenum need to be validated. The following horizontal traverse measurements will be performed for each configuration:

1. Hornyak button $[0.635 \mathrm{~cm}(1 / 4-i n)$.$] at 0 \mathrm{~cm}$ (close as possible).

2. 5.08-, 12.7-, and $25.4-\mathrm{cm}(2-, 5-$, and 10-in.) Bonner balls.

Selected NE213 spectrum measurements will be conducted for certain configurations.

\subsubsection{Plenum Streaming Phase}

The objective of this experiment phase is to quantify uncertainties in computing radiation transport in the large upper and lower plenums. 


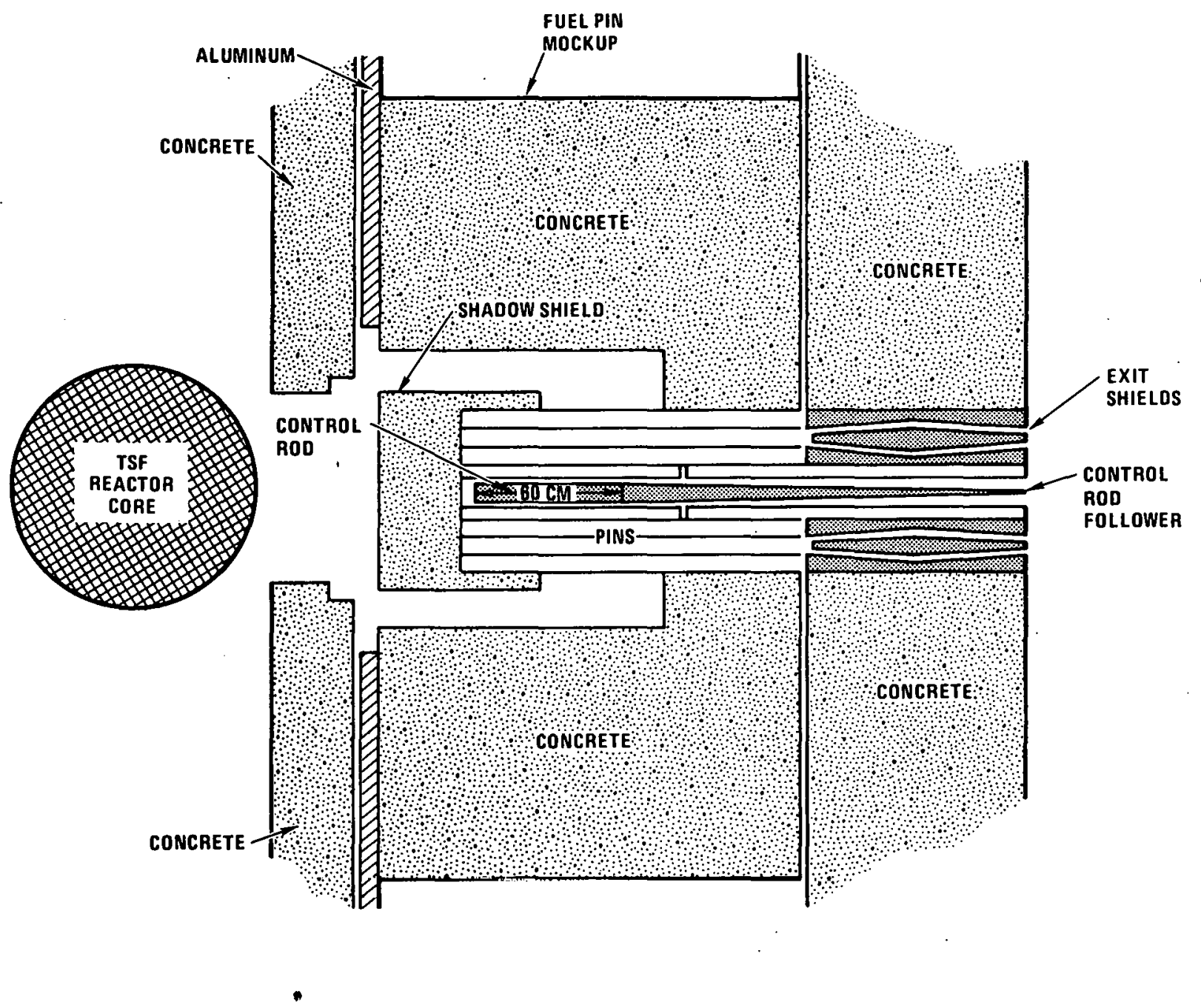

Fig. 4-11. Configuration III: 60-cm (23.6-in.) control rod in core (fully inserted) 


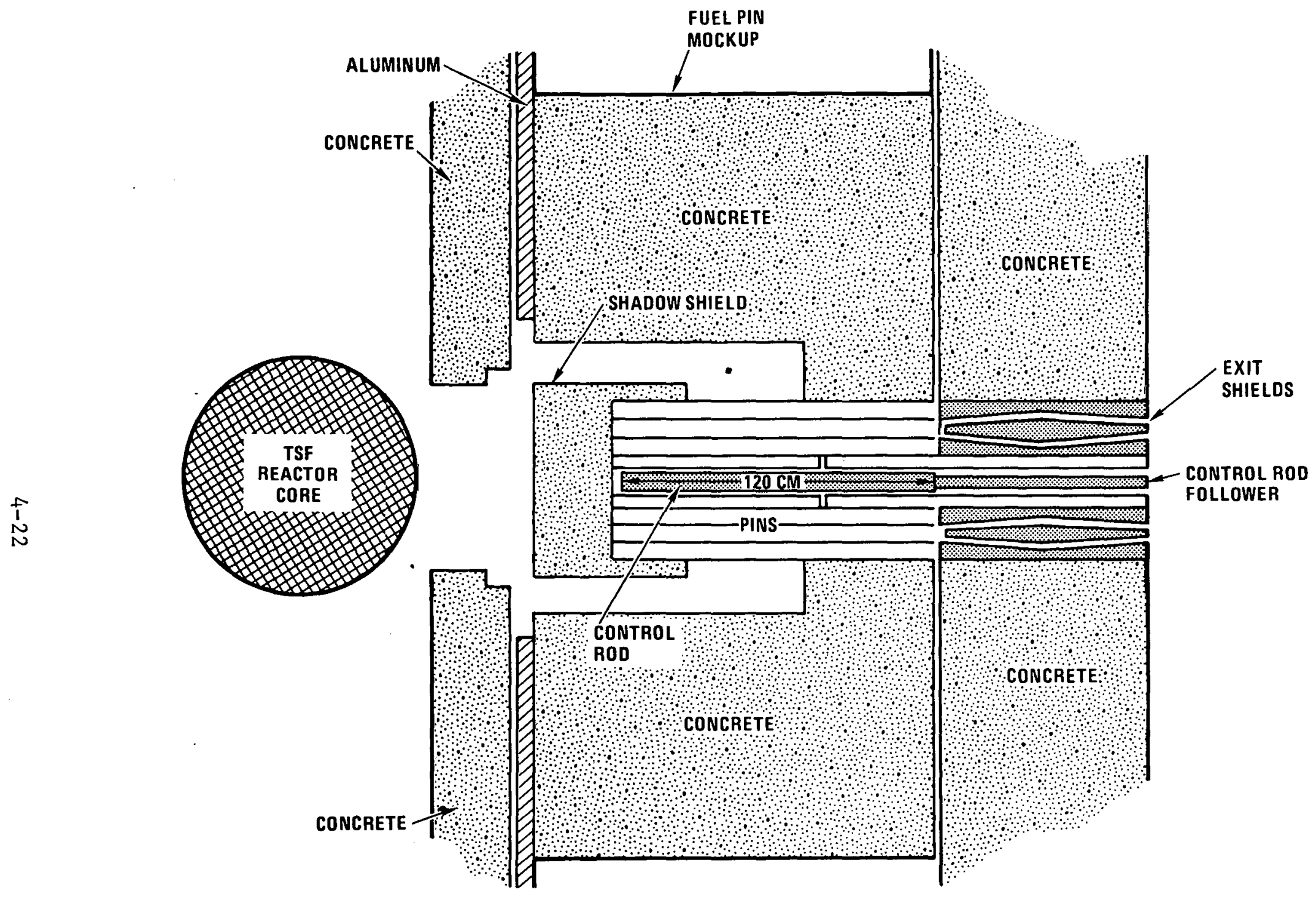

Fig. 4-12. Configuration IV: 120-cm (47.24-in.) control rod in core and blankets (fully inserted) 


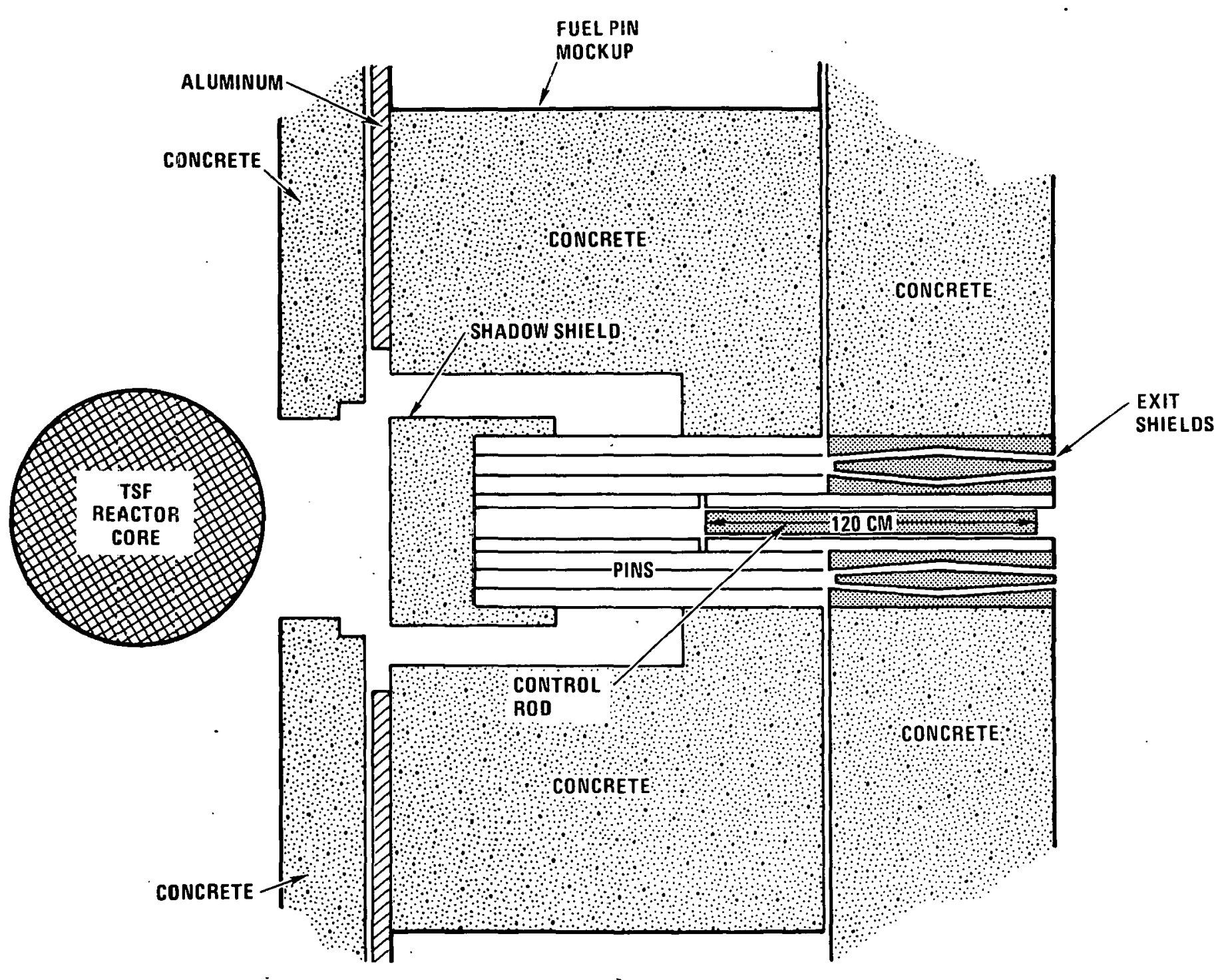

Fig. 4-13. Configuration V: 120-cm (47.24-in.) control rod in blanket and exit shield (fully withdrawn) 


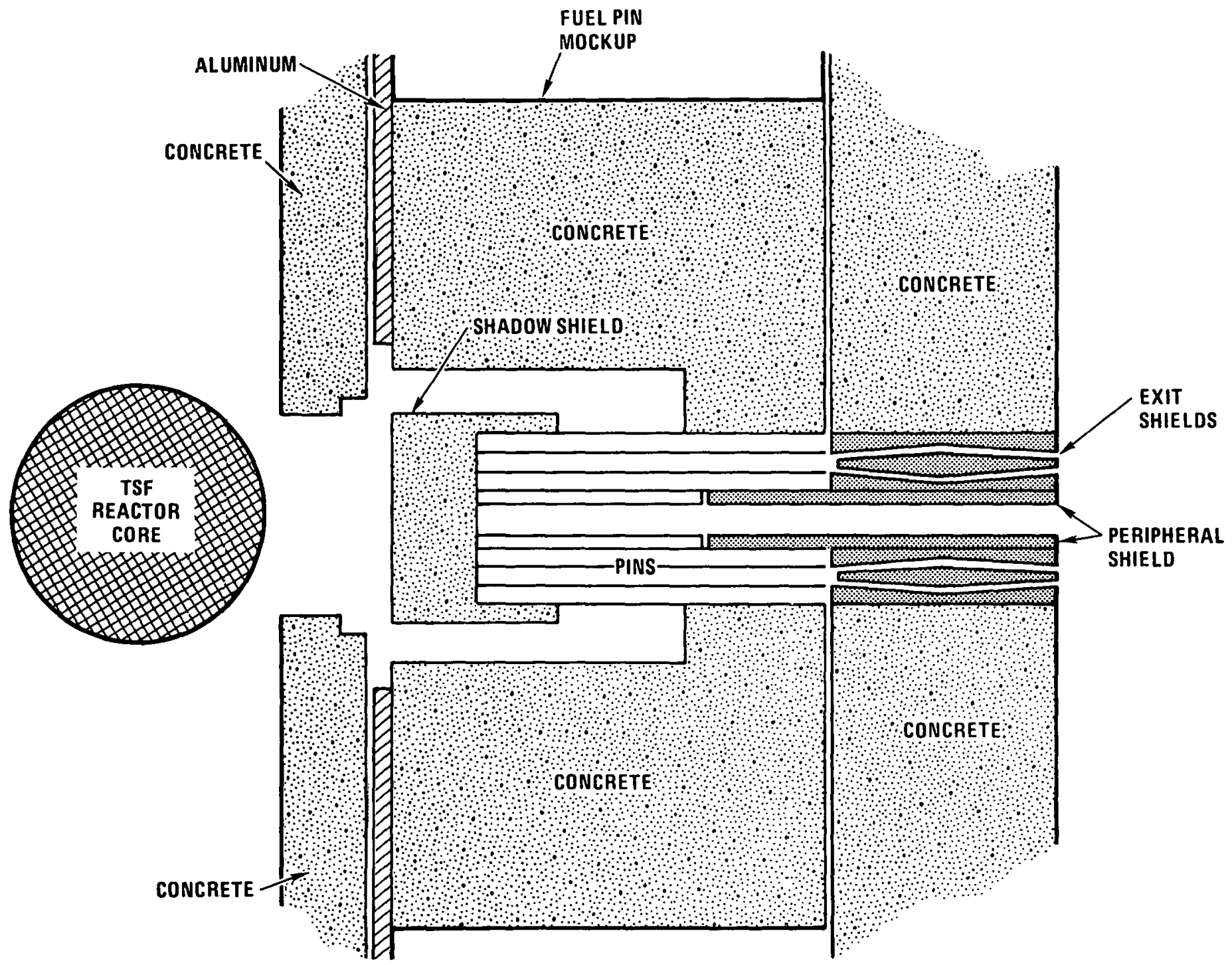

Fig. 4-14. Configuration VI: control assembly with peripheral shield only, no control rod 


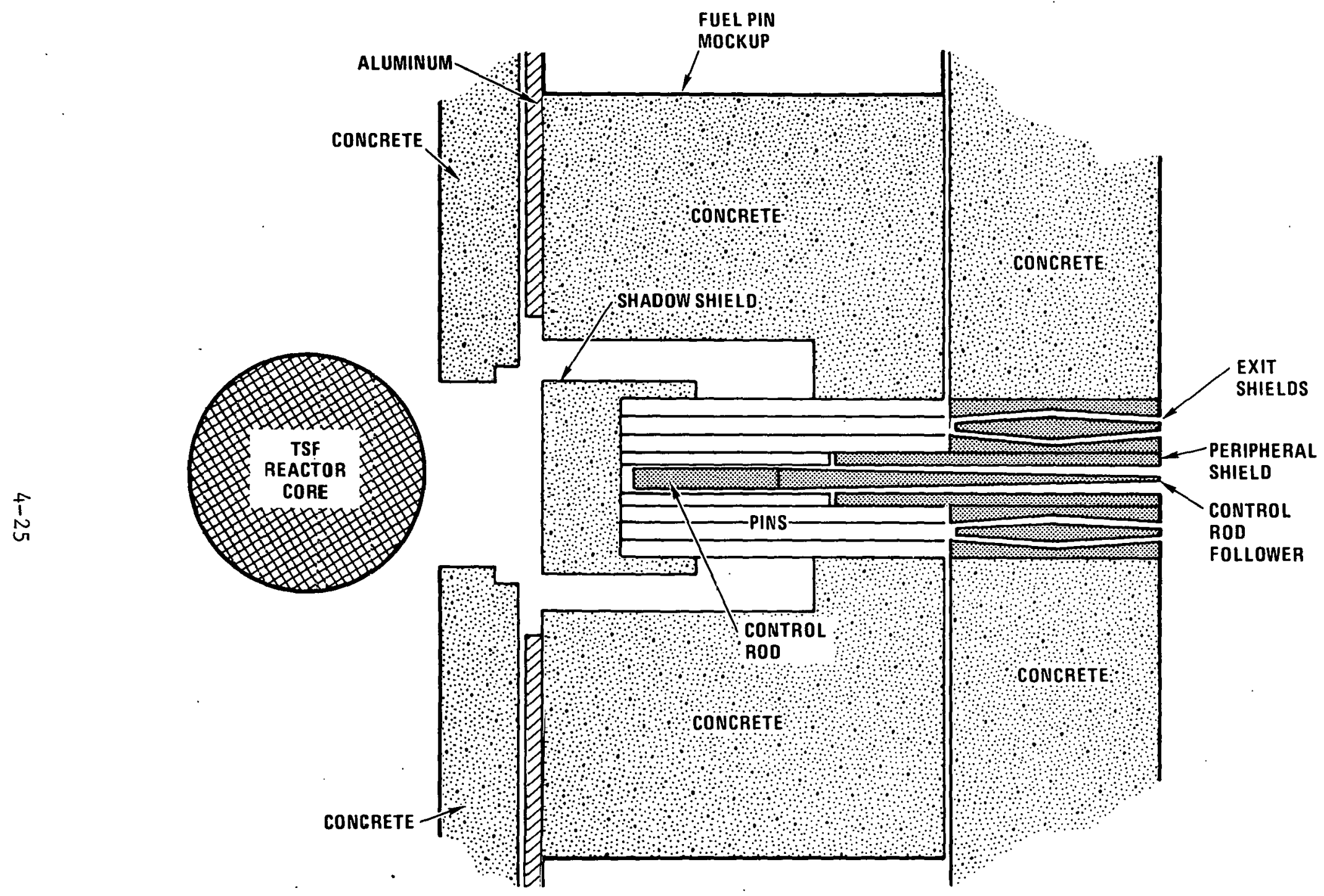

Fig. 4-15. Configuration VII: 60-cm (23.6-in.) control rod in core with peripheral shield 


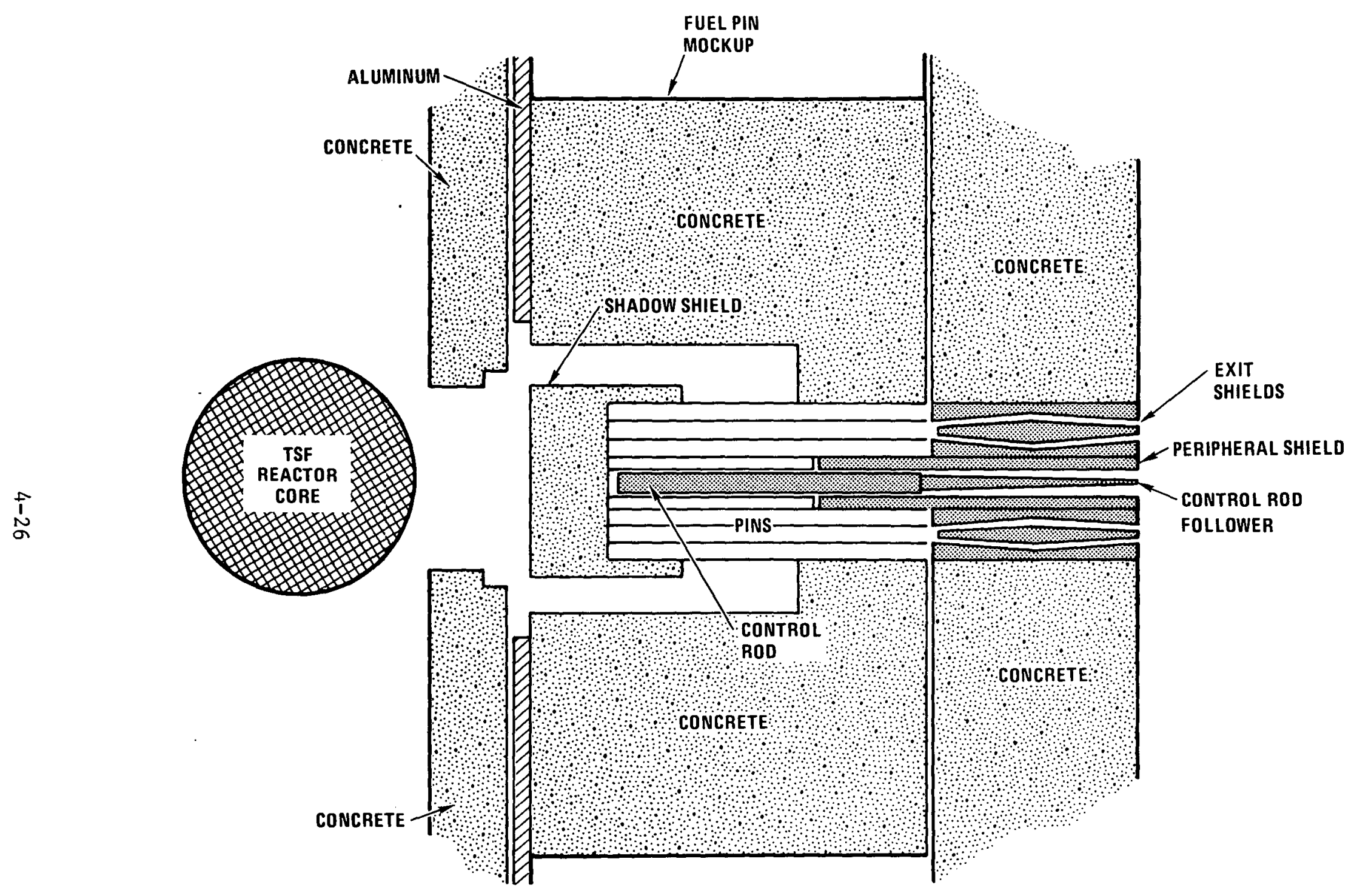

Fig. 4-16. Configuration VIII: $120-\mathrm{cm}$ (47.24-in.) control rod in core and blankets (fully inserted) with peripheral shield 


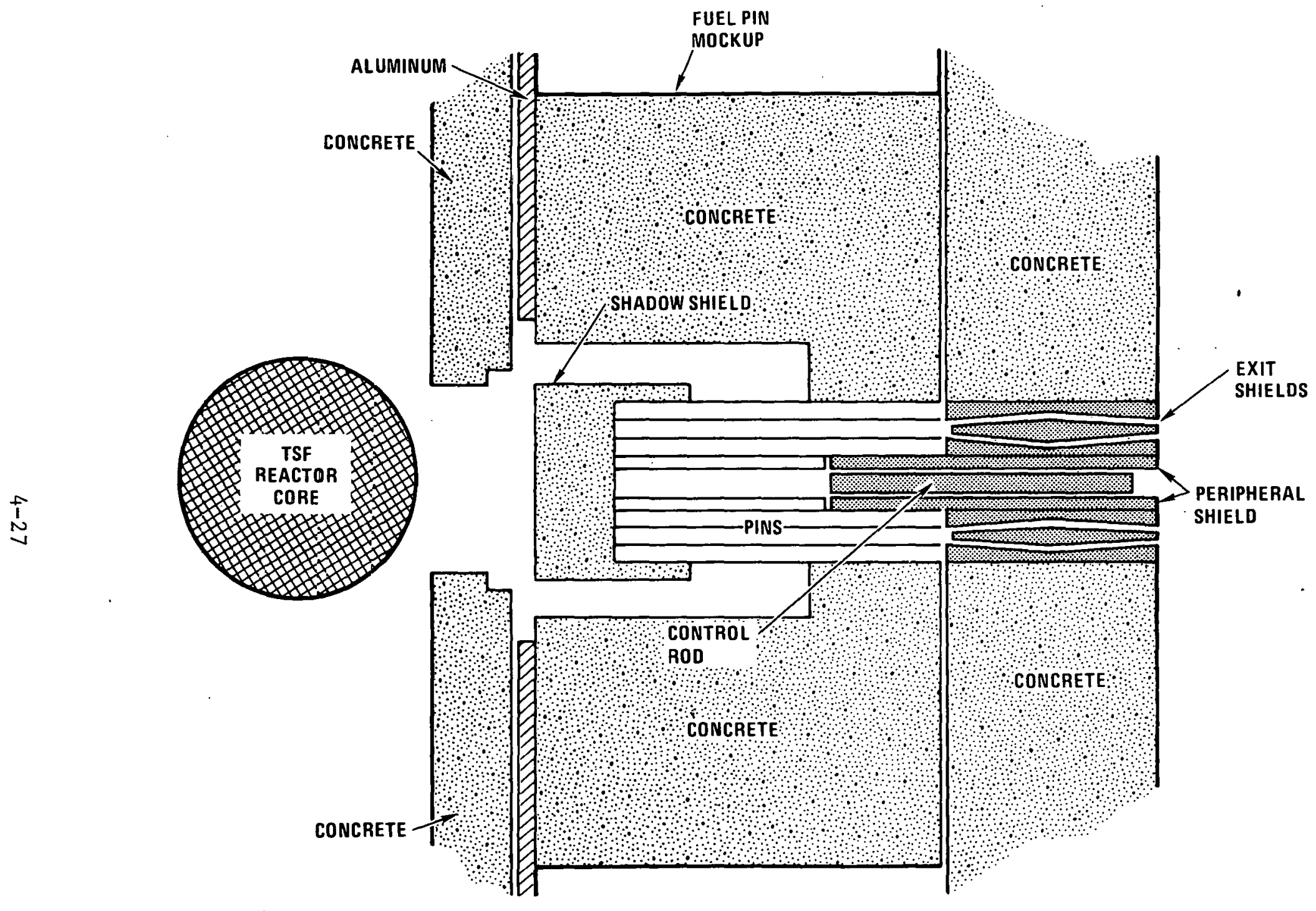

Fig. 4-17. Configuration IX: 120-cm (47.24-in.) control rod in blanket and exit shield (fully witidrawn) with peripheral shield 
scattering off plenum shield surfaces. The following generic criteria - define the test section:

1. The cavity mockups (upper and lower) must be sufficiently large to exhibit the gross transport calculation difficulties associated with large plenums (e.g., ray effects).

2. Since plenum streaming is primarily a geometry effect (except for reflection from plenum walls), the angular dependence of the source into the cavity must be well known.

3. The radial variation of source into the cavity must be minimized or at least well defined.

4. The cavity walls should be lined with materials simulating the scattering characteristics of upper and lower plenum shields.

Figure 4-18 shows the test section mockup fo the plenum streaming phase. Configuration II of the exit shield phase, with seven fuel assemblies and their exit shields, provides a prototypical and well-defined source for the cavity mockup.

The plenum will be sufficiently large for ray effects, if a problem, to be investigated by calculating the experiment with angular quadrature sets varying from coarse to fine angle sets. The concrete cavity walls are lined with 10.16 to $20.32 \mathrm{~cm}$ ( 4 to 8 in.) of graphite covered with a $5.08-\mathrm{cm}$ (2-in.) stainless steel liner, simulating plenum scattering.

The measurement should map the global flux within the cavity and characterize a spectrum. Therefore, measurements are limit'ed to radial and axial traverses with various size Bonner balls. 


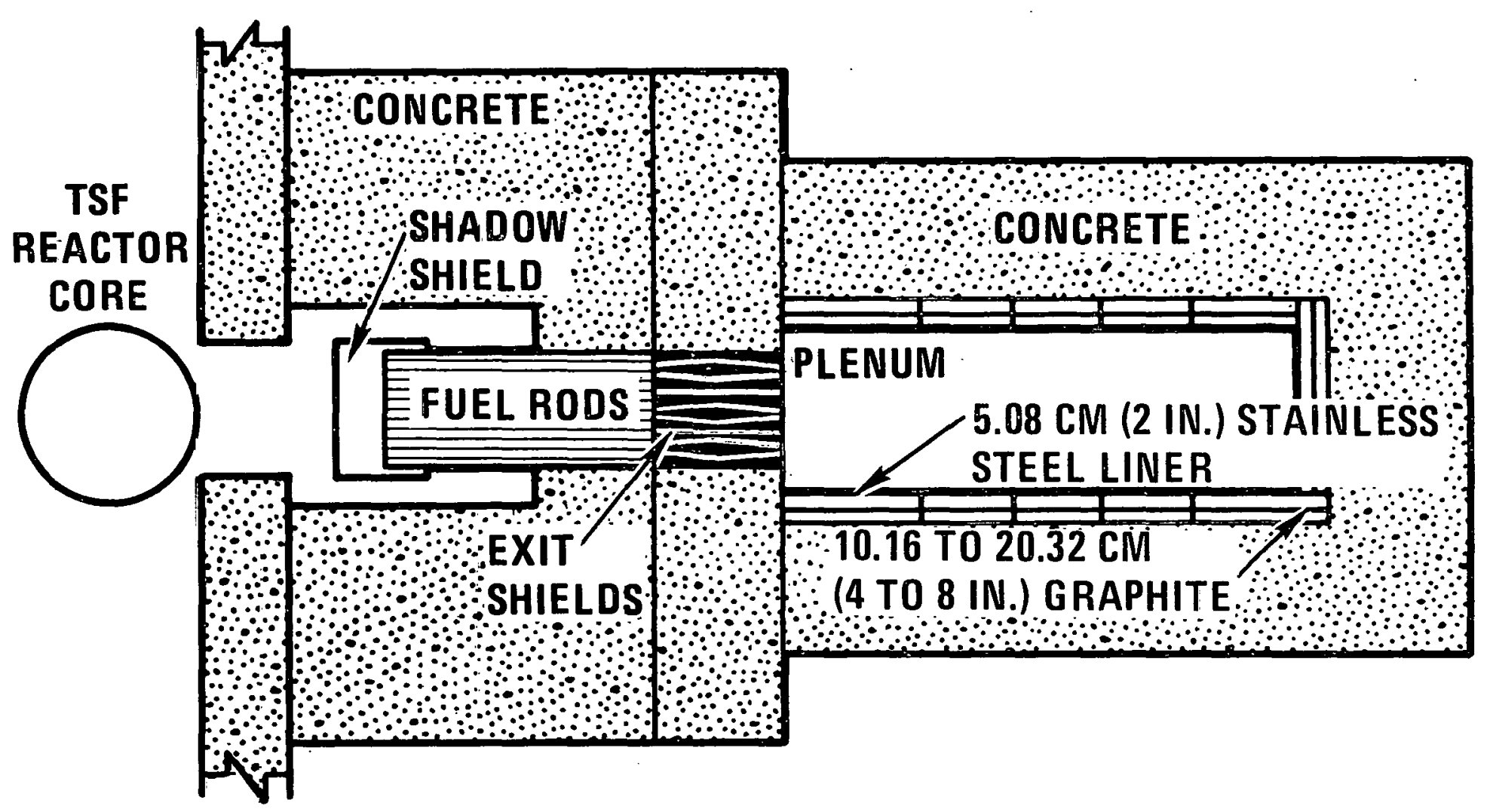

Fig. 4-18. Plenum streaming phase mockup 


\subsubsection{Plenum Shield Simulation Phase}

This experiment phase quantifies uncertainties in computing transport through the as-designed upper and lower plenum shield modules. Figure 4-19 shows the basic experimental configuration. The experiment is in slab geometry, where prototypical plenum shield mockups are placed behind a suitable spectrum modifier. The exact plenum shield dimensions and thicknesses will - correspond to the conceptual design.

Measurements will include local flux peaking with $0.635 \mathrm{~cm}$ (1/4-in.) Hornyak buttons, global flux with various size Bonner balls, and neutron spectrum measurements. 


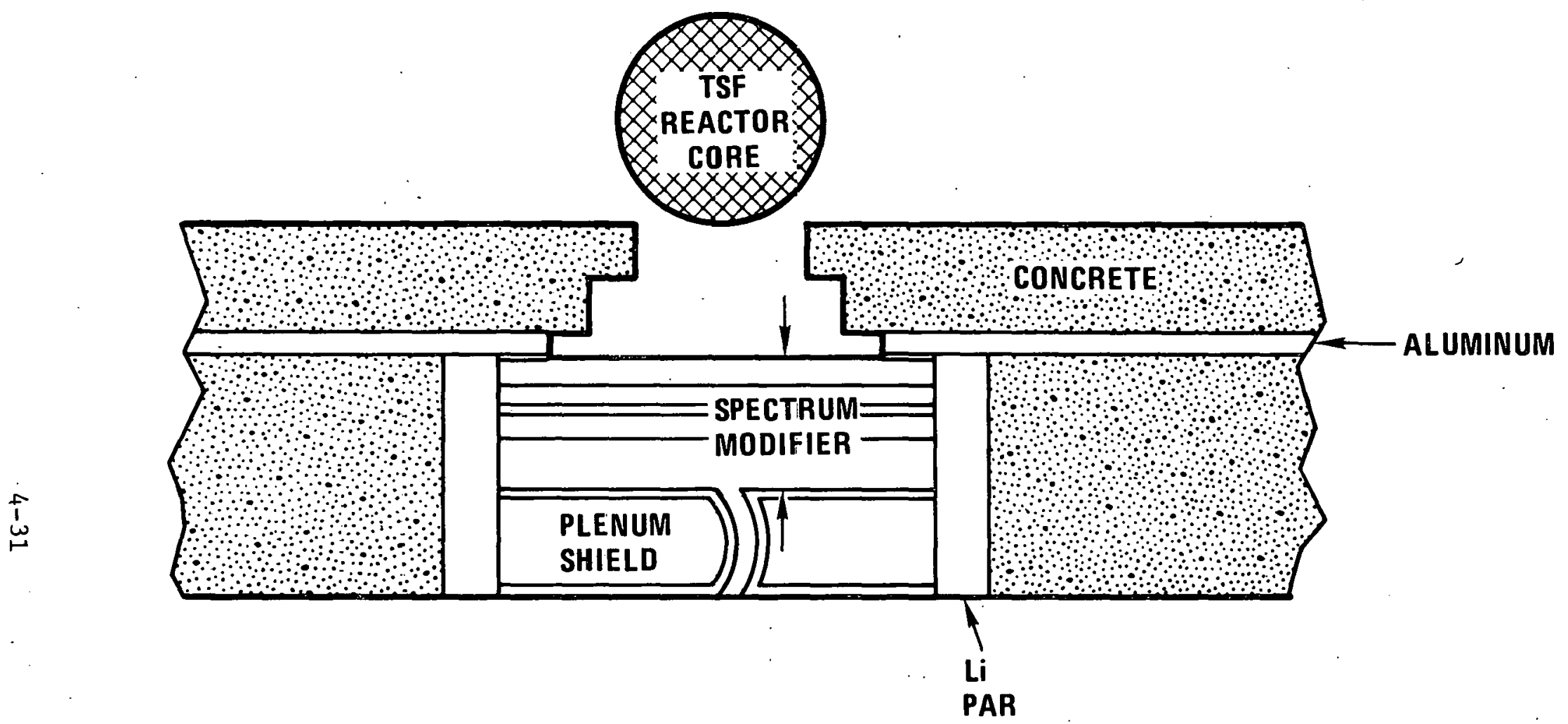

Fig. 4-19. Plenum shield phase mockup 


\section{QUALITY ASSURANCE}

Quality assurance activities for the GCFR plenum streaming experiment will comply with the applicable requirements of 10CFR50, Appendix $B$ (Ref. 10 ), or ANSI N45.2 (Ref. 11). They will especially emphasize the requirements for calibrating test equipment, identifying and controlling materials used in the shielding experiment, and controlling test activities to assure that the test objectives are achieved in a safe, reliable, and predictable manner. Activities will include preanalysis; generation and safekeeping of record data from measurements; postanalysis; and proper dissemination and documentation of data and analysis. These activities will be audited, as appropriate, to assure their compliance with requirements of 10CFR50, Appendix B (Ref. 10), or ANSI N45.2 (Ref. 11) and to assure that the information generated will provide a fully acceptable Nuclear Regülatory Conmission (NRC) 1.icensing data base. 


\section{REFERENCES}

1. Perkins, R., C. Hamilton, and D. Bartine, "GCFR Shielding Design and Supporting Experimental Programs," General Atomic Report GA-A15922, May 1980.

2. Muckenthaler, F: J., J. L. Hull, and J. J. Manning, "The GCFR Grid Plate Shield Design Confirmation Experiment," DOE Report ORNL-TM-6580, Oak Ridge National Laboratory, January 1979.

3. Slater, C., S. Cramer, and D. Ingersoll, "Analysis of the ORNL/TSF GCFR Grid Plate Shield Design Confirmation Experiment," DOE Report ORNL5551, Oak Ridge National Laboratory, August 1979.

4. Ingersol1, D., and F. Muckenthaler, "Deep Penetration Integral. Experiment for a. Thorium Blanket Mockup," International Conference on Nuclear Cross Sections for Technology, October 22-26, 1979, Knoxville, Tennessee.

5. Moen, R. A., et al., "Neutron Fluence Limit Determinations for Some Fast Flux Test Facility Components," Irradiation Effects on Structural Alloys for Nuclear Reactor Applications, STP 484, ASTM, 1970.

6. National Program Plan - Irradiation Effects on the Mechanical Properties of LMFBR Structural Materials," Hanford Engineering Development Laboratory Report TC-810, March 1, 1977.

7. Rouse, C. A., R. G. Perkins, and J. Hom, "GCFR Shielding Status Report-1977," General Atomic unpublished data, May 1978.

8. Perkins, R. G., C. A. Rouse, and C. J. Hamilton, "Design of the GCFR Demonstration Plant Reactor Shielding System," Trans. Am. Nucl: Soc., 33, 704-705 (1979).

9. Perkins, R. G., and R. J. Cerbone, "Physics Design of the 300-MW(e) GCFR Demonstration Plant Grid Plate Shielding, "ERDA Report GA-A14124, General Atomic Company, September 1976. 
10. "Quality Assurance Criteria for Nuclear Power Plants and Fuel Reprocessing Plants," in Code of Federal Regulations, Title 10, Part 50, Appendix B, U.S. Government Printing Office, Washington, D.C., 1977.

11. "Quality Assurance Program Requirements for Nuclear Facilities," American National Standards Institute Standard ANSI/ASME N45.2, 1977. 


\section{GENERAL ATOMIC COMPANY}

P. O. BOX 81608

SAN DIEGO, CALIFORNIA 92138 